\title{
Seasonal and diel differences in dive and haul-out behavior of adult and subadult ringed seals (Pusa hispida) in the Bering and Chukchi seas
}

\author{
Justin A. Crawford ${ }^{1} \cdot$ Kathryn J. Frost ${ }^{2} \cdot$ Lori T. Quakenbush $^{1} \cdot$ Alex Whiting $^{3}$
}

Received: 13 March 2018 / Revised: 5 September 2018 / Accepted: 13 September 2018 / Published online: 15 October 2018

(c) The Author(s) 2018

\begin{abstract}
Changing environmental conditions in the Pacific Arctic are expected to affect ice-adapted marine food webs. As such, understanding ringed seal (Pusa hispida) dive and haul-out behavior is vital to understanding if and how these environmental changes affect seal foraging behavior. Working with Alaska Native subsistence hunters, we tagged 14 adult and 20 subadult ringed seals with satellite-linked data recorders in Kotzebue Sound, Alaska, during late-September and October 2007-2009. Information about dive and haul-out behavior in the Bering and Chukchi seas was collected for 12-297 days. We analyzed indices of dive depth, duration, and rate, and haul-out probability using a model selection framework for adults during fall (late-September-November) and winter (December-March) and for subadults during fall, winter, and also spring (AprilJune). We found differences by season and time of day, but not by sex. Where subadults and adults occurred together, they dove to similar depths; although subadults were commonly located in deeper waters where they generally dove deeper than adults. Both age classes dove longer during winter and subadults tended to make a few more ( 3.5$)$ dives per hour than adults. Both age classes hauled out less and dove deeper, longer, and more frequently during midday than at other times of day. We suspect that seals dive deeper during midday because their prey migrates deeper. Dive and haul-out behaviors of ringed seals are influenced by a combination of factors, including prey distribution and abundance, sea ice, and seal diving physiology.
\end{abstract}

Keywords Diel behavior $\cdot$ Sea ice $\cdot$ Pacific Arctic

\section{Introduction}

Ringed seals (Pusa [also Phoca] hispida) are small phocids that live in seasonally ice-covered waters and have a northern circumpolar distribution (McLaren 1958; Burns 1970; Frost and Lowry 1981). They are the most widely distributed and abundant pinniped in the Arctic (Reeves 1998), are an important subsistence resource for coastal people, are the

Electronic supplementary material The online version of this article (doi:https://doi.org/10.1007/s00300-018-2399-x) contains supplementary material, which is available to authorized users.

Justin A. Crawford

Justin.Crawford@alaska.gov

1 Alaska Department of Fish and Game, 1300 College Road, Fairbanks, AK 99701, USA

2 73-4388 Paiaha Street, Kailua-Kona, HI 96740, USA

3 Native Village of Kotzebue, Box 296, Kotzebue, AK 99752 , USA primary prey of polar bears (Ursus maritimus), and provide an important link between lower and upper trophic levels (e.g., Welch et al. 1992; Stirling 2002). Ringed seal distribution and life history are strongly associated with the presence of sea ice; as such, there is concern that recent reductions in sea ice may affect ringed seal health and survival (Kelly et al. 2010b). Ringed seals use sea ice as a platform for pupping and molting, and for resting between diving bouts at times of year when ice is present (Chapskii 1940; McLaren 1958; Burns 1970; Smith 1973; Frost and Lowry 1981). They winter in shorefast and pack ice habitats. The ability of adults of both sexes to construct and maintain breathing holes as the ice thickens by scratching with their claws and to construct resting lairs adjacent to those holes under snowdrifts allows ringed seals to occupy areas of solid and near solid ice cover in winter (Smith and Stirling 1975). Adult females also construct pupping lairs, around which adult males are thought to defend breeding territories (McLaren 1958; Smith and Stirling 1975; Krafft et al. 2007; Kelly et al. 2010a). Breeding adults typically occupy small home 
ranges under the shorefast ice $\left(<3 \mathrm{~km}^{2}\right.$; Kelly et al. 2010a). Most subadult seals, however, are found in drifting pack ice (McLaren 1958; Smith and Hammill 1981; Hammill and Smith 1989; Furgal et al. 1996; Freitas et al. 2008a; Crawford et al. 2012). In the Bering Sea, subadults show preference for the southern ice edge in winter, while adults prefer ice habitats away from the ice edge (Crawford et al. 2012). These differences in habitat use may reduce intraspecific competition between subadults and breeding adults. Adults require stable shorefast ice to maximize reproductive fitness. Subadults, however, have no such requirement and can feed at the highly productive, but less stable, ice edge, where there are fewer predators (i.e., polar bears), to maximize energy intake for growth (Bradstreet and Cross 1982; Walsh and McRoy 1986; Springer et al. 1996; Stirling 1997; Grebmeier et al. 2006).

Although the dive behavior of ringed seals has been studied in the North Atlantic using seals instrumented with depth recorders (Lydersen and Hammill 1993; Stewart et al. 1996; Teilmann et al. 1999; Gjertz et al. 2000; Born et al. 2002, 2004), fewer studies have been conducted in the Bering, Chukchi, or Beaufort seas (Kelly and Wartzok 1996; Harwood et al. 2012). In this study, we compare the dive and haul-out behavior of 14 adult and 20 subadult ringed seals tagged during 2007-2009 in Kotzebue Sound, Alaska. Although the movements of the seals tagged in 2007 and 2008 have been described by Crawford et al. (2012), their dive and haul-out behavior has not. Here, we include an additional year of movement data (2009) and examine dive and haul-out behavior relative to season and time of day for both age classes to better understand ringed seal dive behavior and how it might relate to foraging.

\section{Methods}

\section{Capture and tagging}

During September and October of 2007-2009, we captured ringed seals in Kotzebue Sound, Alaska $\left(67.0^{\circ} \mathrm{N}, 162.9^{\circ}\right.$ W) using entanglement nets (see Crawford et al. 2012). Entangled seals were brought into a boat, transferred to hoop nets, and taken to shore. Sex and body mass $( \pm 0.5 \mathrm{~kg})$ were recorded for all seals. Ringed seals $\geq 35 \mathrm{~kg}$ were considered adults and only seals weighing $\geq 20 \mathrm{~kg}$ received satellite-linked data recorders (tags) (Crawford et al. 2012). Seals were physically restrained, as necessary, while tags were glued to the hair on their mid-dorsal surface using quick-setting epoxy (Fedak et al. 1983; Stewart et al. 1989). Ringed seals molt annually, between mid-May and mid-July (McLaren 1958; Frost and Lowry 1981); therefore, tags deployed in October were expected to stay attached approximately 8 months. After the epoxy cured, we released the seal at the water's edge, where it was observed until it voluntarily entered the water. All capture activities and much of the seal tagging was conducted by trained Alaska Native subsistence hunters from Kotzebue, Alaska, who were authorized as coinvestigators under the research permit.

Seals were instrumented with SPLASH tags (manufactured by Wildlife Computers, Redmond, WA, USA) that provided summary statistics of dive and haul-out behavior in addition to location. Tags weighed $105 \mathrm{~g}$ in air, measured $78 \times 50 \times 23 \mathrm{~mm}$, and were powered by $2 \mathrm{AA}$ lithium cells. To optimize battery life, we programmed tags to transmit data daily, but only during hours of optimal satellite coverage (0200-2300 local time) and for a maximum of 150 transmissions per day, beginning at 00:00 UTC.

Dive data collected by the tags included the following: DEPTH, the count of dives to depths within predetermined depth (m) intervals (bins); DURATION, the count of dives in different intervals of dive duration (min); and time-atdepth (TAD), the overall time spent within different depth intervals, transmitted as proportion of time (min). Tags stored dive data (histograms) in 14 user-defined bins that encompassed the bathymetry in areas used by the seals in this study (Online Resource 1). Pressure transducers in the tags sampled pressure (depth) every $10 \mathrm{~s}$ and estimated tag depth within a $0-1000 \mathrm{~m}$ depth range at a resolution of $\pm 0.5 \mathrm{~m}$. The start and end of a dive was determined by a saltwater switch that sensed the transition from wet to dry and only dives $>2 \mathrm{~m}$ depth were analyzed. Dive data were recorded in four 6-h periods: 0300-0859 (morning), 0900-1459 (midday), 1500-2059 (evening), and 2100-0259 (night), matching those used in similar studies of dive behavior (Teilmann et al. 1999; Frost et al. 2001; Born et al. 2002; Folkow et al. 2004; Hastings et al. 2004; Nordøy et al. 2008) but corresponding to local time at $165-180^{\circ} \mathrm{W}$. The tags also collected hourly timelines of the proportion of each hour the tag reported being out of the water and dry (presumed to be hauled out). A minute was classified as "dry" if the tag was dry for $\geq 30$ s of that minute. These data were stored on the tags until transmitted to Service Argos satellites, or for up to two days. If not transmitted within two days, the data were overwritten by more recent data. A saltwater switch ensured that transmissions occurred only when the tags were at the surface and out of the seawater.

\section{Data analysis}

\section{Location data}

Dive histograms are not associated with locations when downloaded from the Argos satellites. Decoding software provided by Wildlife Computers assigned one location for all four 6-h histograms each day (Wildlife Computers 2012). One location every $24 \mathrm{~h}$, however, was not sufficient 
to associate dive locations with bathymetry and sea ice data. To locate where dives occurred, we estimated the seal's position at the middle of each 6-h histogram from Argos locations using the continuous-time Correlated Random Walk (CRW) model developed by Johnson et al. (2008). The model, which treats movement as a velocity process, is available in the statistical package crawl, version 3.1, in $\mathrm{R}$ (R Core Team 2014). We estimated two parameters, $\beta$, the autocorrelation in velocity and $\sigma$, the variation in velocity. Location error was assumed to be normally distributed with a mean of 0 . Argos locations with quality scores 3, 2, and 1 have estimated standard deviations of $250 \mathrm{~m}, 500 \mathrm{~m}$, and $1500 \mathrm{~m}$, respectively, but standard deviations for poor quality location scores $(0, \mathrm{~A}$, and $\mathrm{B})$ are not estimated (see the Argos user's manual: https://www.argos-system.org/manual/) (Fancy et al. 1988; Stewart et al. 1989; Harris et al. 1990). To incorporate location measurement error for poor quality locations into the seal movement model, we used the error distributions from Johnson et al. (2008:1211), which are based upon the observations of Vincent et al. (2002). We did not use the "stopping model" of Johnson et al. (2008) which accounts for periods when animals are stationary. Although adults of both sexes may occupy small home ranges and haul out on stable, stationary shorefast ice during the breeding season (Kelly et al. 2010a), adults we tagged were not stationary and did not maintain small territories (Crawford et al. 2012). Similarly, subadults throughout the year and adults in summer and autumn haul out on pack ice and nearshore ice remnants that drift and are not stationary (Burns et al. 1981).

The CRW model has trouble fitting locations when Argos error is excessive, i.e., larger than measured values and priors (Johnson et al. 2008). Therefore, prior to fitting the CRW model, we filtered the Argos locations to remove extreme outliers using a Speed-Distance-Angle (SDA) filter in R package argosfilter (Freitas et al. 2008b). The filter first removes all locations with unrealistic swim speeds ( $>2.5 \mathrm{~m} / \mathrm{s}$; Williams and Kooyman 1985; Lowry et al. 1998), unless the location is $<5 \mathrm{~km}$ from the previous location. Within $5 \mathrm{~km}$, locations are filtered using angular thresholds because velocity thresholds remove many goodquality locations where estimated swim speeds are high simply due to locations being recorded close in time. The angular threshold removes locations that form acute angles away from the path of movement. These "spikes" in the path of movement are characteristically outliers and erroneous. We removed locations that formed angles $<15^{\circ}$ in the path of movement when they were farther than $2.5 \mathrm{~km}$ from the previous location. Locations that formed angles $<25^{\circ}$ were removed if they were farther than $5 \mathrm{~km}$ from the previous location. Thus, only locations that fall far from the path of movement are removed, not those within a short distance (Freitas et al. 2008b). Prior to fitting the CRW model, we reviewed all locations retained by the SDA-filter in ArcMap 10.0 (ESRI Inc. 2010) and removed locations that were on land.

We examined ringed seal dive behavior relative to water depth and the presence and coverage of sea ice. We used locations estimated from the CRW model to determine the location of dives summarized in a histogram and then assigned bathymetry and sea ice concentration (every 4th day) to them using the Spatial Analyst Tool (Extract Values to Points) in ArcMap 10. Bathymetry data came from a 1-km digital elevation model produced by the Alaska Ocean Observing System (AOOS; Danielson et al. 2008). Sea ice concentration data came from the Advanced Microwave Scanning Radiometer-Earth (AMSR-E) Observing System $(12.5 \mathrm{~km})$ imagery available through the National Snow and Ice Data Center (Cavalieri et al. 2004). We extracted values from the AMSR-E data and assigned ice concentrations to each 6-h dive location estimated by the CRW model, based on the $12.5 \mathrm{~km}$ grid within which it was located.

\section{Dive indices}

We examined patterns in three indices of dive behavior based upon (1) dive depth, (2) dive duration, and (3) dive rate (Folkow and Blix 1999; Folkow et al. 2004, 2010). Each 6-h histogram has 14 separate depth bins. The goal of calculating indices is to reduce the amount of data contained within the histograms such that subsequent analyses can focus on a single variable, yet still retain important patterns within the histogram data. The dive depth and dive duration indices used data from the DEPTH $(\mathrm{m})$ and DURATION (min) histograms, respectively, and were calculated using the methods of Folkow and Blix (1999):

$\operatorname{Index}_{x}=\sum\left(f_{i} M_{i}\right)$

where $x$ is the type of index (dive depth or dive duration), $f_{i}$ is the proportion of dives assigned to the depth/duration bin $i$, and $M_{i}$ is the median depth/duration value of bin $i$.

The index of dive rate was calculated by summing the total number of dives $>2 \mathrm{~m}$ depth in each 6-h DEPTH histogram and then dividing by 6 to yield an hourly dive rate. Although the depth resolution of the tags was high $( \pm 0.5 \mathrm{~m})$, we excluded dives $<2 \mathrm{~m}$ to eliminate issues of wave height and near-surface behavior that may not be related to foraging (Hastings et al. 2004; Folkow et al. 2010). We also calculated the probability of a seal being hauled out (haul-out probability) for each hour of the day using the hourly timeline haul-out data, which stores the proportion of each hour the tag reported being dry (i.e., out of the water). An hour was classified as "hauled out" if the tag was out of the water for $\geq 30 \mathrm{~min}$ of that hour. We did not use the proportion of time spent in different depth bins in the time-at-depth (TAD) 
histograms to examine dive behavior because even though ringed seals sometimes forage during the descent and ascent phases of dives (Simpkins et al. 2001), TAD also includes the time spent traveling through depth bins to the foraging depth. However, we did use TAD data to validate interpretations of dive rate and time seals spent at the surface.

\section{Statistical analysis}

We used a linear model selection framework to test for the significance of covariates on our indices of dive behavior. The dependent variable, the dive index, is from a limited number of seals that were measured repeatedly. Therefore, to account for repeated observations from the same animal and obtain valid estimates of error and the proper $p$ values, we used repeated-measures mixed models (Ramsey and Schafer 2002; PROC MIXED). Individuals were treated as random effects to allow for heterogeneity in dive behavior. To account for autocorrelated dive behavior and unequal time spacing among repeated measures within individuals, we used a spatial power covariance matrix structure (SP(POW)). Haul-out probabilities are binary data (i.e., the seal was either hauled out during the hour or not), therefore we modeled the haul-out probabilities using logistic regression. Again, we treated individuals as random effects and used a spatial power model to account for repeated measures; these models were fitted within PROC GLIMMIX. Our global models included all the explanatory variables of interest (see below). The model we used for inference was selected using a backward elimination procedure that sequentially eliminated statistically non-significant variables $(P>0.05)$ until only statistically significant variables remained $(P<0.05)$. All analyses were performed with SAS software (version 9.3, SAS Institute Inc 2011).

We were particularly interested in whether dive and haul-out behavior differed by season and, separately, by ice concentration. Seasons in the Bering and Chukchi seas (fall: late-September-November; winter: December-March, and spring: April-June), however, are largely confounded with the movement and concentration of sea ice. Fall begins with predominantly open-water conditions when the southern edge of the sea ice is located in the northern Chukchi and southern Beaufort seas and progresses as day-length shortens and the ice edge advances south (Fig. 1). Winter is characterized by short day-length and the continued southward advance of sea ice through Bering Strait toward its southern-most extent in the Bering Sea; shorefast ice forms along the coast and heavy pack ice forms offshore. In spring, day-length increases and the sea ice retreats north through the Bering Sea and eventually through Bering Strait. To determine whether season or ice concentration better explained variation in dive and haul-out data, we compared dive depth, duration, rate, and haul-out probability models that included only season to models with only ice concentration and models with both variables using second-order Akaike's Information Criterion adjusted for small sample size $\left(\mathrm{AIC}_{\mathrm{C}}\right)$. In all models, season provided a more parsimonious explanation of dive and haul-out behavior than ice concentration or both variables in the same model $\left(\Delta \mathrm{AIC}_{\mathrm{C}}\right.$ range between season and the second ranked model: 5.5-732.5), and therefore, we did not include ice concentration in our models.

For each index of dive behavior (i.e., each dependent variable), we examined the relationship between the index and (1) sex, (2) season, and (3) time of day (morning, midday, evening, and night). Because haul-out data were summarized hourly, we modeled the haul-out probability as a function of hour of day instead of the 6-h periods corresponding to the histogram data.

Sex, season, time of day, and the interaction of Season $\times$ Time of day were modeled in an additive fashion. Sex was not significant in any preliminary models and was not included as an interaction variable. Dive behavior during spring was analyzed for subadults $(n=8)$ but not adults due to their low sample size $(n=2)$ during this season. Adults and subadults were generally located in different areas, especially during winter; therefore, comparing age classes in the same model could provide misleading statistical interactions and inaccurate interpretations of behavior. As such, we modeled each dive index and haul-out probability separately for each age class to reduce interactions and more clearly interpret similarities and differences. Throughout the text we report results as means $\pm 95 \%$ confidence limit interval. Due to the large number of comparisons that were analyzed, $P$ values are not presented in the text; comparisons were considered significant when $P<0.05$.

Subadult ringed seals in the Chukchi and Bering seas migrate south to the ice edge during winter, while adults remain farther north in regions of shorefast and heavy pack ice (Crawford et al. 2012). To evaluate whether the dive behavior of adults and subadults differed only because of geographic location (i.e., subadults near the southern ice edge in deeper water, adults farther north in and near shorefast ice), we analyzed a subset of our data from adults and subadults that were present in the same region at the same time. Specifically, we constrained this analysis to the greater Bering Strait region, from St. Lawrence Island north to Point Hope. We then repeated the analyses described above, comparing dive indices for depth, duration, and rate by season to evaluate differences by age class. We averaged and plotted the dive depth and duration indices that fell within $20 \times 20 \mathrm{~km}$ raster cells in ArcMap 10.0 to visually compare their spatial distribution. 

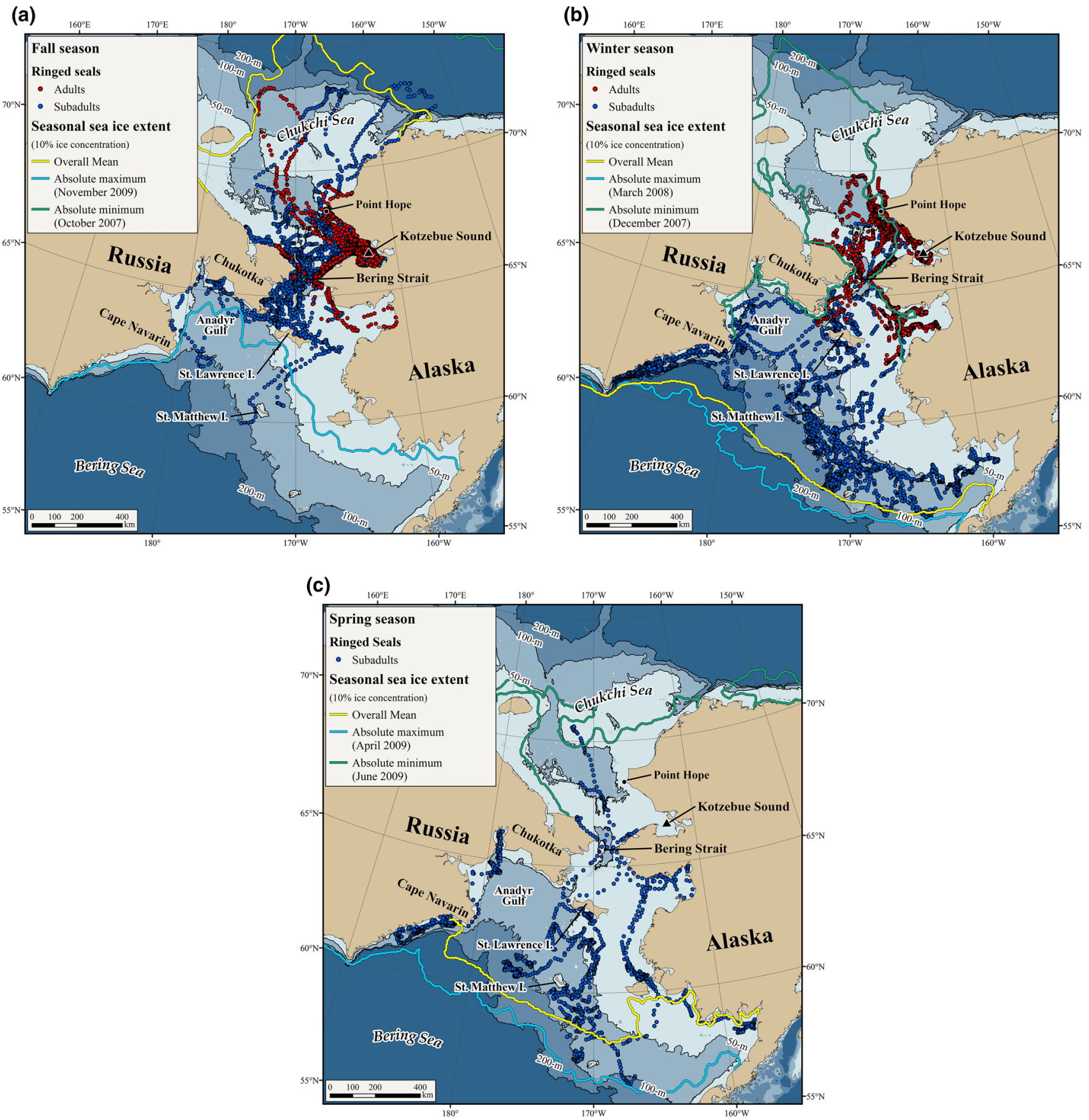

Fig. 1 Estimated dive locations of tagged adult and subadult ringed seals (Pusa hispida) in the Bering and Chukchi seas during a fall (late-September-November; 14 adults and 20 subadults), b winter (December-March; 13 adults and 12 subadults), and $\mathbf{c}$ spring (AprilJune; 8 subadults), 2007-2010. Seasonal sea ice extents represent the $10 \%$ ice concentration based on Advanced Microwave Scanning

\section{Results}

\section{Tagged seals and tag performance}

We analyzed data from 34 ringed seals: 21 males ( 8 adult, 13 subadult) and 13 females (6 adult, 7 subadult) tagged
Radiometer-Earth data collected every 4 days (National Snow and Ice Data Center) for: (1) overall mean extent, average of all data during each season, (2) absolute maximum, the farthest ice extent during each season, and (3) absolute minimum, the least ice extent during each season, from 2007 to 2010

in late-September and October (Online Resource 2). Adults averaged $45.7 \mathrm{~kg} \pm 3.6 \mathrm{~kg}$, while subadults averaged $24.9 \mathrm{~kg} \pm 1.8 \mathrm{~kg}$ (Online Resource 2).

Tags transmitted for an average of 132 days and seals were located on $86 \%$ of these days. Seals tagged in 2008 were tracked longer (190 days) than seals tagged in 2009 
(103 days) and 2007 (98 days). Eight of the tags deployed in 2008 transmitted at least until the following March, and five until June or longer. Only two of the tags deployed in 2007 and three in 2009 were still transmitting in March $(n=12$ each year; Online Resource 2).

Duration of tracking, proportion of days located, total locations acquired, and number of locations per day did not differ by sex or age class (Table 1). The CRW model used 28,325 locations accepted by the SDA-filter to estimate 19,836 locations that matched the dive histogram data (four locations per day at 6-h intervals).

\section{Seasonal movements and ice cover}

Movements of seals tagged in 2009 were similar to those of the seals tagged in 2007 and 2008 and described by Crawford et al. (2012); adults and subadults were generally located in different areas, especially during winter when subadults moved south into the Bering Sea with the advancing sea ice while adults generally stayed farther north. Although adults were located in areas with more ice cover than subadults during winter and fall across all three years of this study, both age classes were located in areas with roughly $50 \%$ more sea ice cover during winter (adults: $88.2 \pm 1.2 \%$; subadults: $71.4 \pm 1.3 \%$ ) than during fall (adults: $38.9 \pm 2.1 \%$; subadults: $20.3 \pm 1.4 \%$ ). During spring, subadults were in areas of intermediate sea ice cover $(30.7 \pm 2.0 \%)$ (Fig. 1c).

\section{Dive and haul-out behavior}

The final model for all dive indices (dive depth, duration, and rate) included season, time of day, and the interaction of season and time of day (Season $\times$ Time of day), except for the model of adult dive depth, which included only time of day. The final models for haul-out behavior (haul-out probabilities) included season, hour of day, and the interaction of season and hour of day (Season $\times$ Hour of day) for both adults and subadults. Sex was not significant for any model of dive index or haul-out probability. Adults and subadults were generally located in different areas; therefore, they were analyzed separately to reduce interactions and more clearly interpret similarities and differences.

\section{Dive depth}

The tags deployed on 34 ringed seals (14 adults and 20 subadults) provided 10,068 dive depth histograms (adult females 1902 histograms; adult males 1650; subadult females 2641; subadult males 3875) representing 1,211,987 individual dives. More than half $(57 \%)$ of all dives were $2-10 \mathrm{~m}$ and only $3 \%$ were $>100 \mathrm{~m}$. The deepest dive during fall was between 100 and $150 \mathrm{~m}$ for adults and between 150 and $200 \mathrm{~m}$ for subadults. The deepest dive during winter was between 50 and $76 \mathrm{~m}$ for adults and between 300 and $350 \mathrm{~m}$ for subadults. Dives deeper than $200 \mathrm{~m}$, however, were uncommon $(<0.03 \%$ of all dives) and only three subadults made dives $>200 \mathrm{~m}$, all in winter.

For adults, dive depth did not differ between fall $(13.1 \pm 3.8 \mathrm{~m})$ and winter $(17.1 \pm 3.8 \mathrm{~m})$ and diel patterns in dive depth were similar by season (Fig. 2). During both seasons, adults dove deeper during midday than other times of day, when dive depths were similar (Fig. 2). Adult dive depths were within $5 \%$ of the ocean floor (i.e., they dove to the ocean floor) more often during fall (39\%), when mean water depths were the shallowest $(15.7 \mathrm{~m})$, than winter (31\%), when mean water depths were deeper $(25.4 \mathrm{~m})$.

Subadults dove deeper during spring $(37.9 \pm 2.9 \mathrm{~m})$ than winter $(32.3 \pm 3.0 \mathrm{~m})$, which was deeper than fall $(21.2 \pm 3.2 \mathrm{~m})$ and, like adults, diel patterns in dive depth were similar among seasons (Fig. 2). During all seasons, subadults dove from 5 to $17 \mathrm{~m}$ deeper during midday than night and differences between midday dives and morning and evening dives were greater during fall and winter than spring (Fig. 2). Subadults dove to the ocean floor $18 \%$ less often than adults during fall (21\%) and winter (13\%) when mean water depths were similar (61.3 and $65.9 \mathrm{~m})$. Except for dives during winter at midday, most subadult dives were $<30 \mathrm{~m}$ during fall and winter. Subadults dove closer to the ocean floor during spring (36\%), when mean water depths were shallower $(50.5 \mathrm{~m})$, and, except for dives at night, most subadult dives were $\geq 40 \mathrm{~m}$ (Fig. 2).

In general, subadults dove deeper than adults during fall and winter (Fig. 2). However, adults spent more time in shallower water where dive depth was restricted by water depth,
Table 1 Performance summary of satellite tags attached to ringed seals (Pusa hispida) in Kotzebue Sound and monitored in the Bering and Chukchi seas, 2007-2010

\begin{tabular}{lllll}
\hline Age class & Tracking days & \% days located & Total locations $^{\mathrm{a}}$ & Locations/day $^{\text {a }}$ \\
\hline Adult, $n=14$ & 117.9 & 80.6 & 616.4 & 5.8 \\
Ranges & $40-277$ & $53.2-100$ & $166-1032$ & $2.3-11.1$ \\
95\% CL & $80.7-155$ & $72.1-88.5$ & $443.6-757.8$ & $4.3-7.1$ \\
Subadult, $n=20$ & 141.5 & 89.5 & 861.2 & 6.9 \\
Ranges & $20-297$ & $55.9-100$ & $178-1995$ & $3.0-10.8$ \\
$95 \%$ CL & $93.9-189.1$ & $83.5-95.6$ & $564.4-1157.9$ & $5.8-8.1$ \\
\hline
\end{tabular}

Adults and subadults were not statistically different in any category

${ }^{\mathrm{a}}$ Total number of locations after the SDA filtering process 
Fig. 2 Dive depth indices (meters) of tagged adult $(n=14)$ and subadult $(n=20)$ ringed seals (Pusa hispida) in the Bering and Chukchi seas, 2007-2010, based on season (fall: late-September-November, winter: December-March, spring: April-June (only subadults)) and time of day (morning: 0300-0859, midday: 0900-1459, evening: 1500-2059, night: 2100-0259). Error bars represent $95 \%$ confidence intervals around means. Wide gray bars in background represent mean bathymetry for seal dive locations. Numbers of ringed seals with tags transmitting each season are presented below bathymetry bars

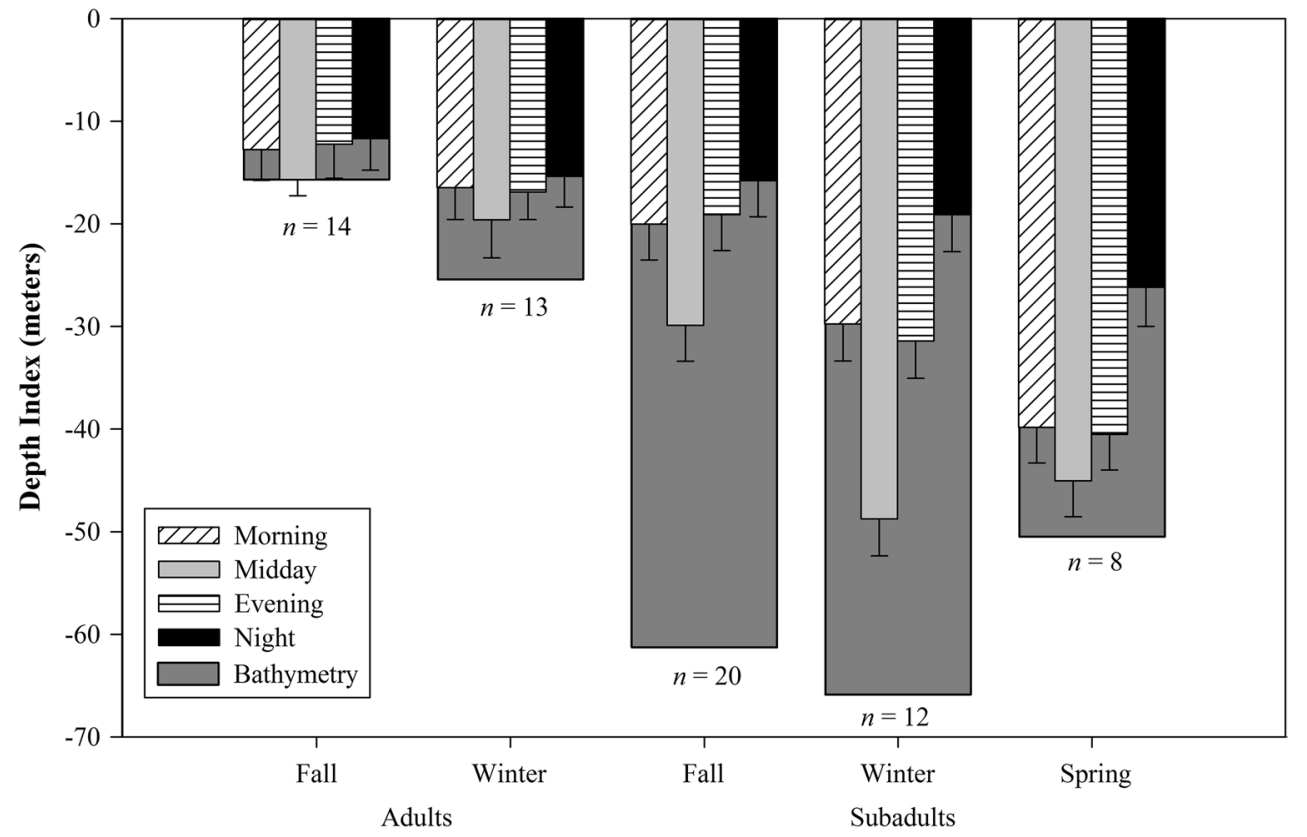

Age class and Season and therefore adults used more of the water column when diving.

\section{Dive duration}

Our dataset included 10,024 dive duration histograms (adult females 1936 histograms; adult males 1595; subadult females 2621; subadult males 3871) representing 1,188,112 individual dives. Overall, dive duration ranged from $<1 \mathrm{~min}$ to $10 \mathrm{~min} ; 49 \%$ of all dives were $<1 \mathrm{~min}$ and $90 \%$ were $<4 \mathrm{~min}$. For adults, dive duration was longer during winter $(2.7 \pm 0.4 \mathrm{~min})$ than fall $(2.0 \pm 0.3 \mathrm{~min})$ and diel patterns in dive duration were similar between seasons, generally with longer dives during midday (Fig. 3).

Subadults dove longest during spring $(2.6 \pm 0.2 \mathrm{~min})$ followed by winter $(2.2 \pm 0.2 \mathrm{~min})$ and fall $(1.8 \pm 0.2 \mathrm{~min})$. Diel patterns in dive duration were generally similar between fall and winter when subadults dove longest during midday (Fig. 3). During spring, however midday dive duration was not different than morning and evening; night dives were shorter (Fig. 3).

In general, within each season that could be compared, adults and subadults dove for similar durations (Fig. 3). Diel patterns of dive duration were also similar between adult and subadult seals (see duration indices and CLs above and Fig. 3).

\section{Dive rate}

The final models for dive rate for adults and subadults were the same as for duration (i.e., Season $\times$ Time of day).
Overall, seals made $<20$ dives/h during $72 \%$ of the periods and $>30$ dives $/ \mathrm{h} 7 \%$ of the periods.

Dive rate of adults was similar between seasons except that during the morning it was higher in fall (fall: $14.7 \pm 0.7$ dives/h; winter: 13.0 \pm 0.8 dives/h) (Online Resource 3). Dive rate was higher during midday in both fall and winter than the rest of the day, which were similar during both seasons (Online Resource 3).

Dive rate of subadults was higher during fall $(19.2 \pm 0.9$ dives/h) than winter $(16.9 \pm 0.8$ dives $/ \mathrm{h})$, and both were higher than spring $(15.0 \pm 0.8$ dives $/ \mathrm{h})$, but diel patterns of dive rate were different among seasons (Online Resource 3). During fall, dive rate was higher during midday than during the rest of the day, which were all similar. During winter, however, dive rates did not differ by time of day. During spring, dive rate was higher at night than during the rest of the day, which were all similar (Online Resource 3).

In general, adults made fewer dives than subadults during fall $(15.2 \pm 1.3$ vs. $19.2 \pm 0.9$ dives $/ h)$ and winter $(13.9 \pm 1.4$ vs. $16.9 \pm 0.8$ dives/h; Online Resource 3 ). Adult and subadult seals exhibited similar diel patterns of dive rate during fall, but not winter.

\section{Haul-out probability}

Our dataset included 79,056 h (3294 days) of timeline haulout data (adult females 642 days; adult males 527; subadult females 880; subadult males 1245). Hourly haul-out probabilities ranged from 0.05 to 0.15 (5-15\% of hours) for adults and 0.04 to 0.24 (4-24\% of hours) for subadults (Fig. 4). Adults exhibited a strong diel pattern in haul-out behavior 
Fig. 3 Dive duration indices (minutes) of tagged adult $(n=14)$ and subadult $(n=20)$ ringed seals (Pusa hispida) in the Bering and Chukchi seas, 2007-2010, based on season (fall: late-September-November, winter: December-March, spring: April-June (only subadults)) and time of day (morning: 0300-0859, midday: 0900-1459, evening: 1500-2059, night: 2100-0259). Error bars represent 95\% confidence intervals around means. Numbers of ringed seals with tags transmitting each season are presented above confidence intervals

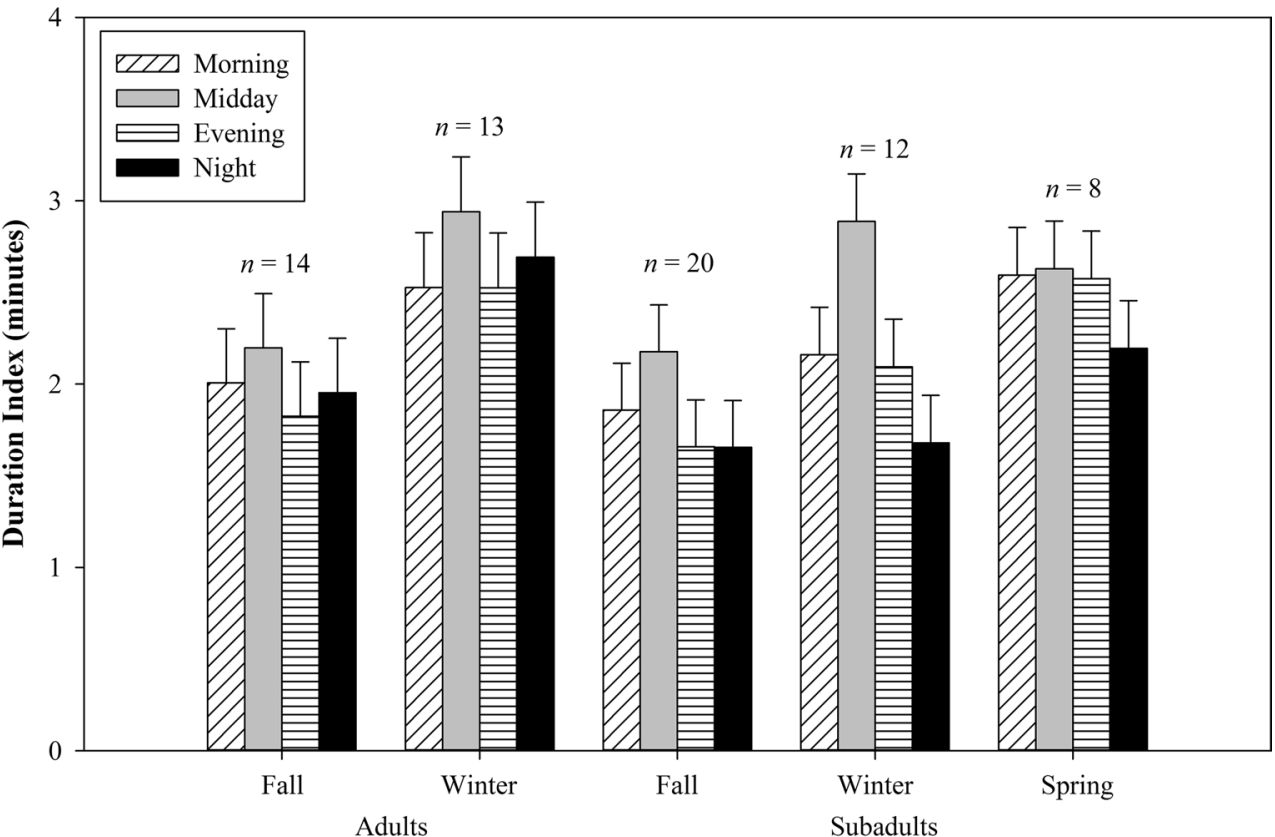

Age class and Season that was evident in both seasons, but strongest during winter. Adults were more likely to be hauled out during the hours of 1900-0300 than 0900-1300, regardless of season (Fig. 4). Between seasons, however, adults were more likely to haul out during the hours of 1900-0300 during the winter than fall. There was no significant difference between seasons during the hours of 0900-1300.
During fall and winter, haul-out probabilities of adults and subadults were similar. Spring data were available only for subadults, which were more likely to haul out during spring $(16.3 \pm 4.7 \%$ of hours) than winter $(12.1 \pm 3.6 \%$ of hours $)$ or fall $(9.3 \pm 2.6 \%$ of hours) (Fig. 4). Diel patterns in haul-out probability were similar during fall and winter; subadults were more likely to haul out from 1900 to 0300 than from 0900 to 1300 (Fig. 4). From 1900 to 0300, subadults were more likely
Fig. 4 Haul-out probabilities for adult and subadult ringed seals (Pusa hispida) in the Bering and Chukchi seas, 2007-2010, based on season (fall: lateSeptember-November, winter: December-March, spring: April-June (only subadults)) for each hour of day. Numbers of ringed seals with tags transmitting each season are listed in the legend

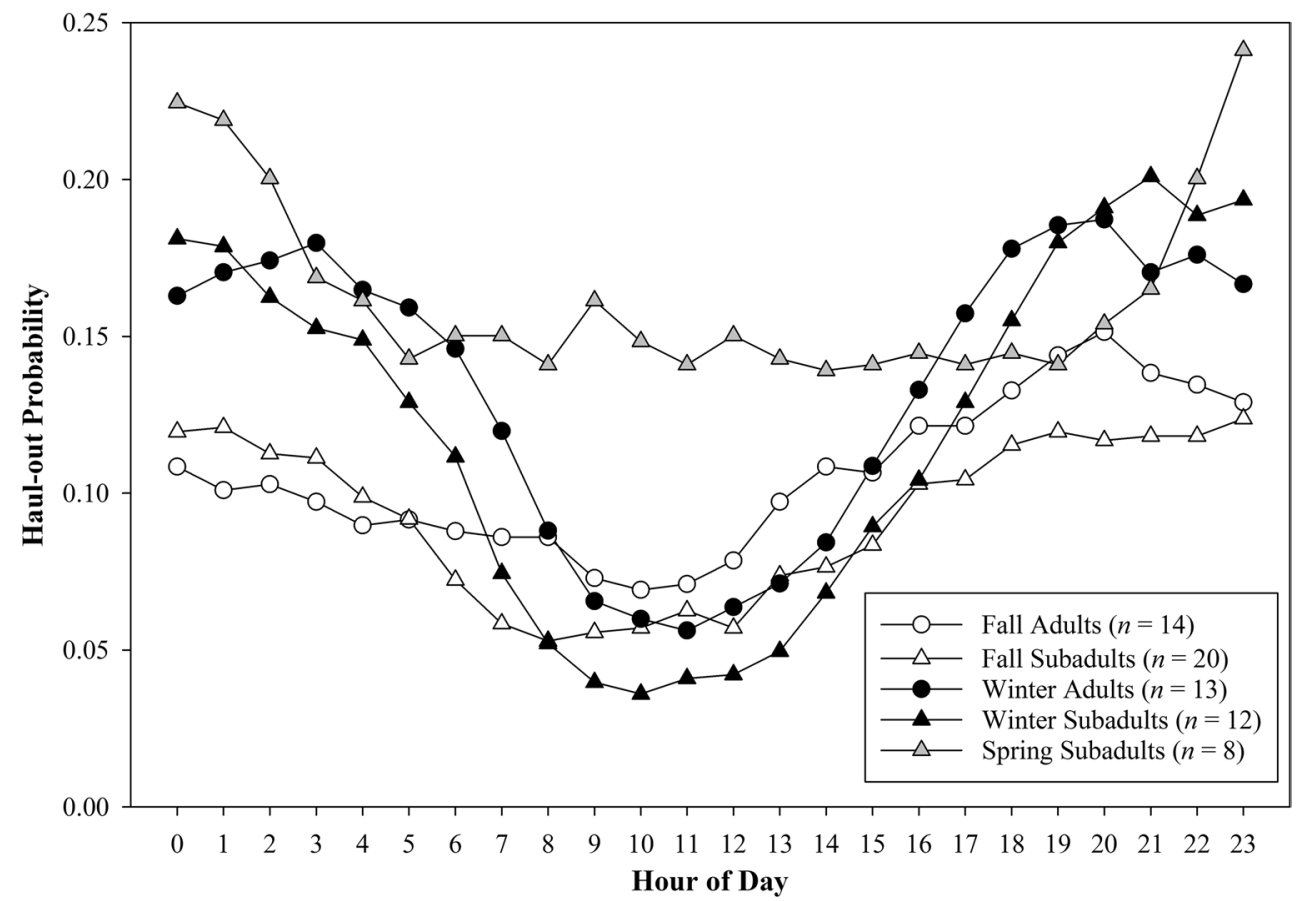


to haul out during winter (15-20\% of hours) than fall (11-12\% of hours). During spring, however, subadults were more likely to haul out from 2200 to 0200 than from 0300 to 2100 .

\section{Dive behavior within the Bering Strait region}

Adults in this study spent most of their time in shallower water than did subadults. For this reason, our overall modeled results indicating that adults did not dive as deeply as subadults may be somewhat misleading. Our analysis of data from the Bering Strait region where adults and subadults were present at the same time indicated that the two age classes dove to similar depths in this area of overlap, ranging from $\sim 20$ to $35 \mathrm{~m}$. Adults and subadults dove to similar average depths during fall $(18.8 \pm 4.3$ and $22.3 \pm 3.1 \mathrm{~m}$, respectively) and winter $(17.9 \pm 4.0$ and $18.1 \pm 5.2 \mathrm{~m}$, respectively) (Figs. 5, 6, and Online Resource 4).

The model results for dive duration, in contrast to dive depth, differed between the area of overlap and the overall analysis. Adults dove longer than subadults in both fall $(2.5 \pm 0.3$ vs. $1.9 \pm 0.2 \mathrm{~min})$ and winter $(2.6 \pm 0.2 \mathrm{vs}$. $1.6 \pm 0.2 \mathrm{~min}$; Figs. 7 and 8). As in the full dataset, both age classes tended to dive more deeply during midday, during which time they made dives of longer duration (Online Resource 5). As in the overall analysis, within the Bering Strait region, subadults dove more frequently than adults in both fall (19.4 \pm 1.4 vs. $16.2 \pm 1.8$ dives/h) and winter $(17.5 \pm 1.7$ vs. $13.1 \pm 1.8$ dives $/ \mathrm{h})$.

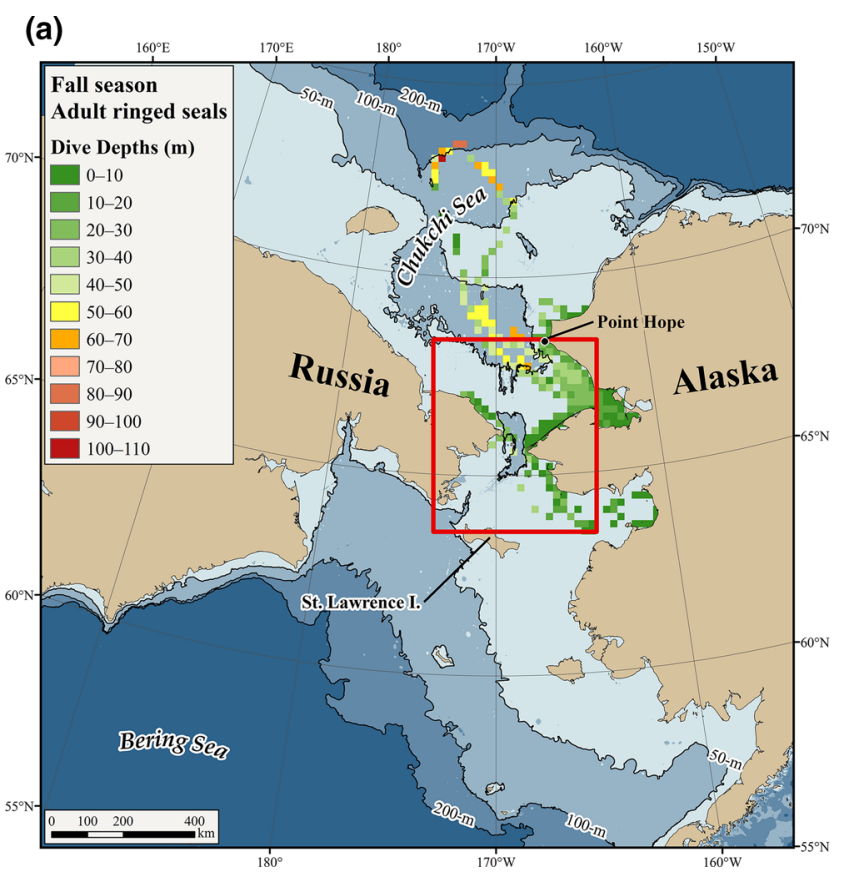

Fig. 5 Spatial distribution of dive depths of tagged a adult $(n=14)$ and $\mathbf{b}$ subadult $(n=20)$ ringed seals (Pusa hispida) during fall (lateSeptember-November) in the Bering and Chukchi seas, 2007-2010.

\section{Discussion}

Ringed seals catch prey by diving and their dive behavior is likely the product of a complex interaction, primarily among age-associated differences in where seals choose to forage, the behavior of their prey, and the physiological constraints of diving. We examined differences in indices of seal dive and haul-out behavior but did not address seal prey or physiology directly. Therefore, our interpretations of these behaviors should be considered in this context.

A few limitations of our data require explanation. First, our analysis of dive behavior used indices of behavior that summarized each 6-h histogram into a single value. This method could over-simplify dive behavior especially if dive data were bimodal (e.g., if seals made frequent dives to $20 \mathrm{~m}$ and $100 \mathrm{~m}$ but dives to intermediate depths were rare). However, we examined the histogram data (dive depth, duration, and rate) by season and age class and did not identify any bimodal behaviors; therefore, we consider these indices to accurately represent dive behavior of ringed seals. Second, we defined seasons by the general patterns observed in the presence or absence of sea ice, which may be associated with other factors that influence seasonal ringed seal behavior, such as ice concentration and thickness, currents, salinity, and wind, which affect prey abundance and distribution. These factors are difficult to measure at the scale of this study. Last, this study combined data from seals tagged in different years, which could confound some analyses due to

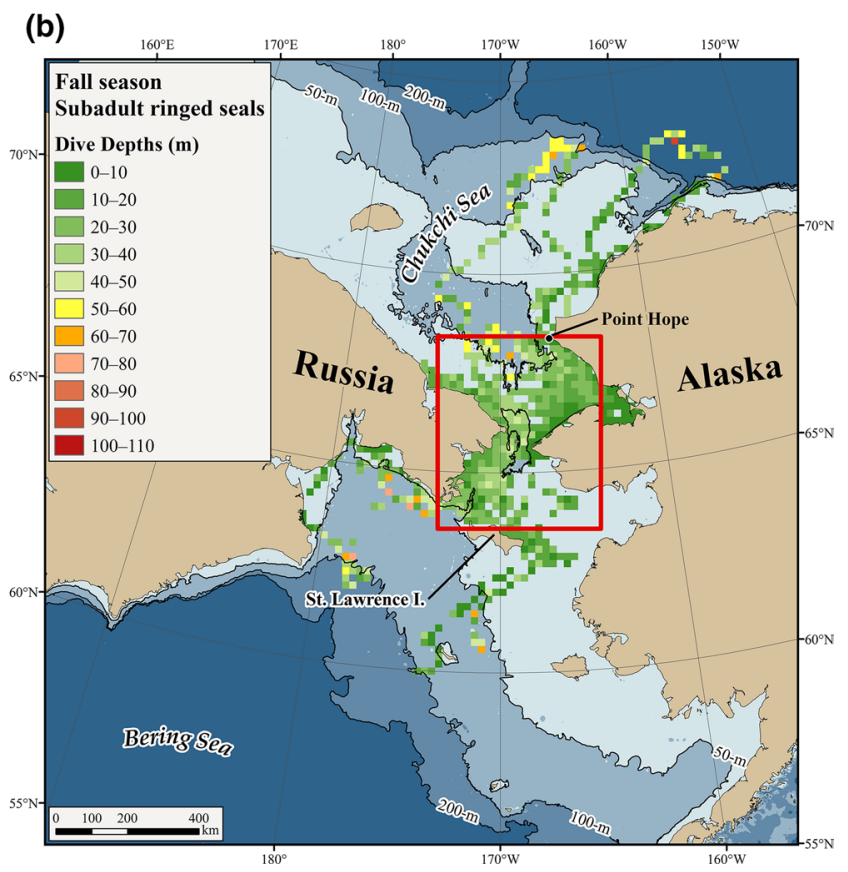

Depth indices were averaged within $20 \times 20 \mathrm{~km}$ cells. Red box represents the area of adult-subadult overlap 


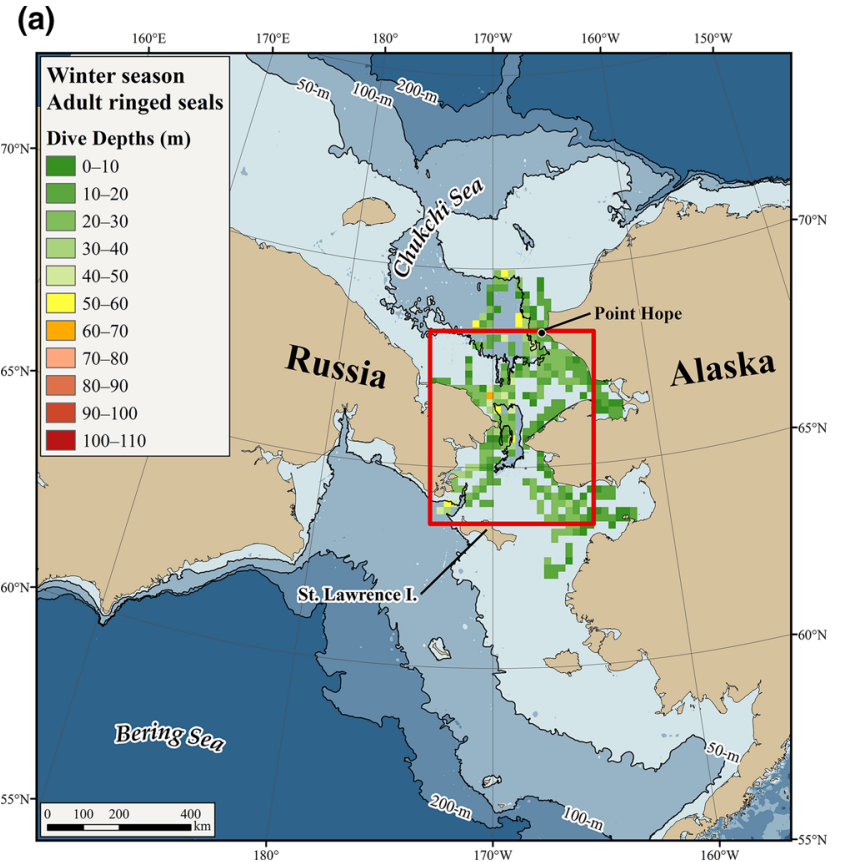

Fig. 6 Spatial distribution of dive depths of tagged a adult $(n=13)$ and b subadult $(n=12)$ ringed seals (Pusa hispida) during winter (December-March) in the Bering and Chukchi seas, 2007-2010.

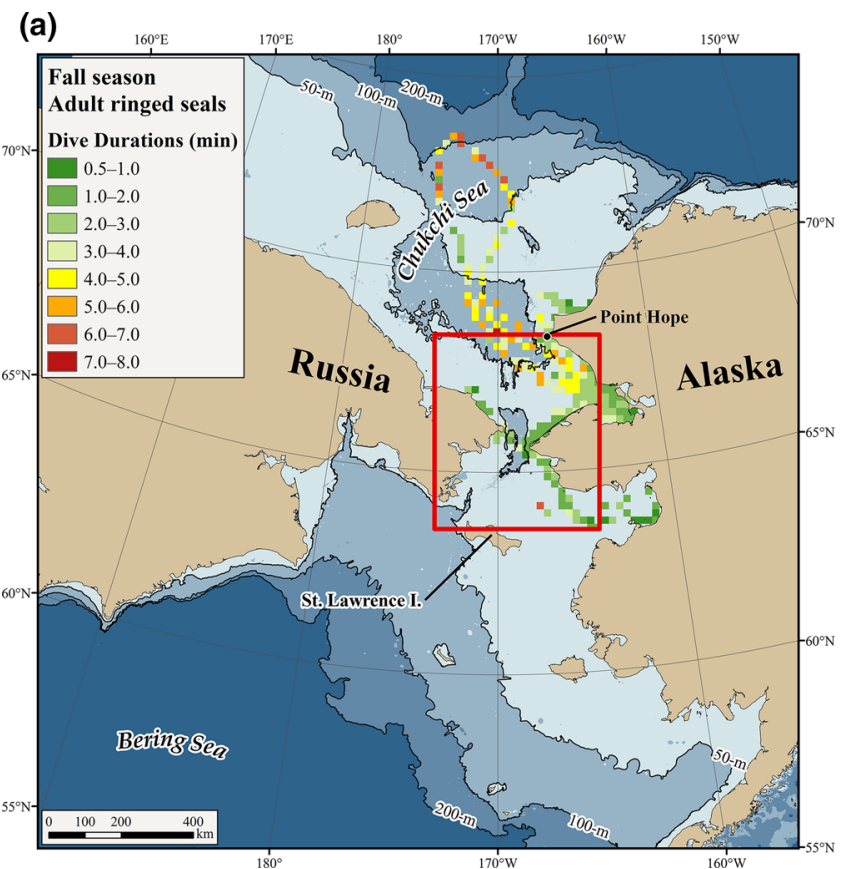

Fig. 7 Spatial distribution of dive durations of tagged a adult $(n=14)$ and b subadult $(n=20)$ ringed seals (Pusa hispida) during fall (lateSeptember-November) in the Bering and Chukchi seas, 2007-2010.

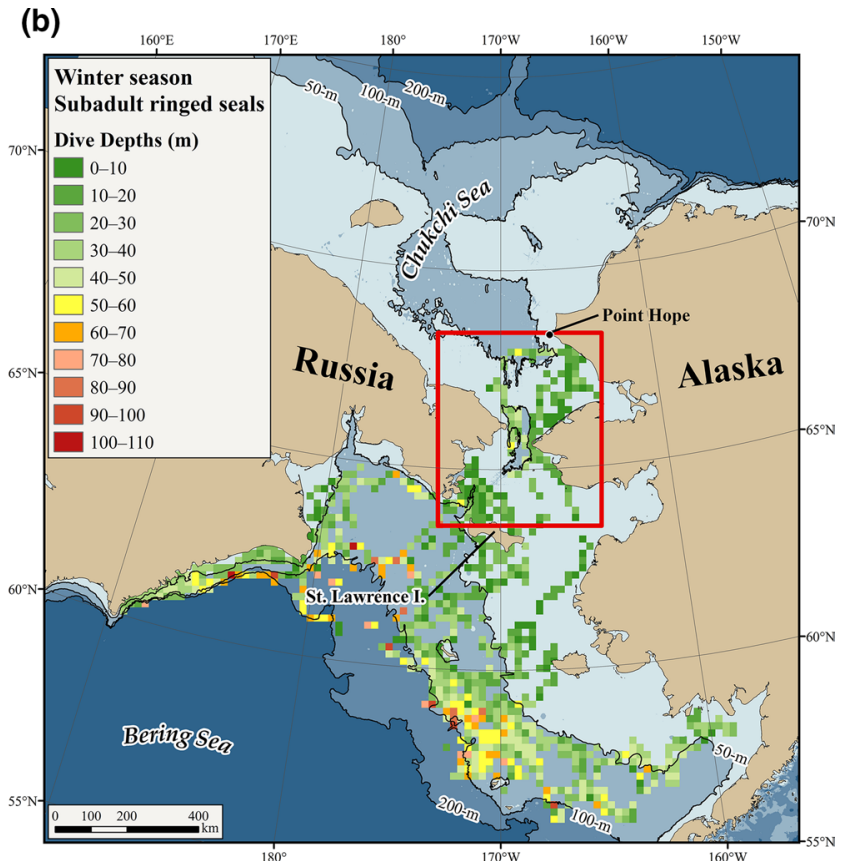

Depth indices were averaged within $20 \times 20 \mathrm{~km}$ cells. Red box represents the area of adult-subadult overlap

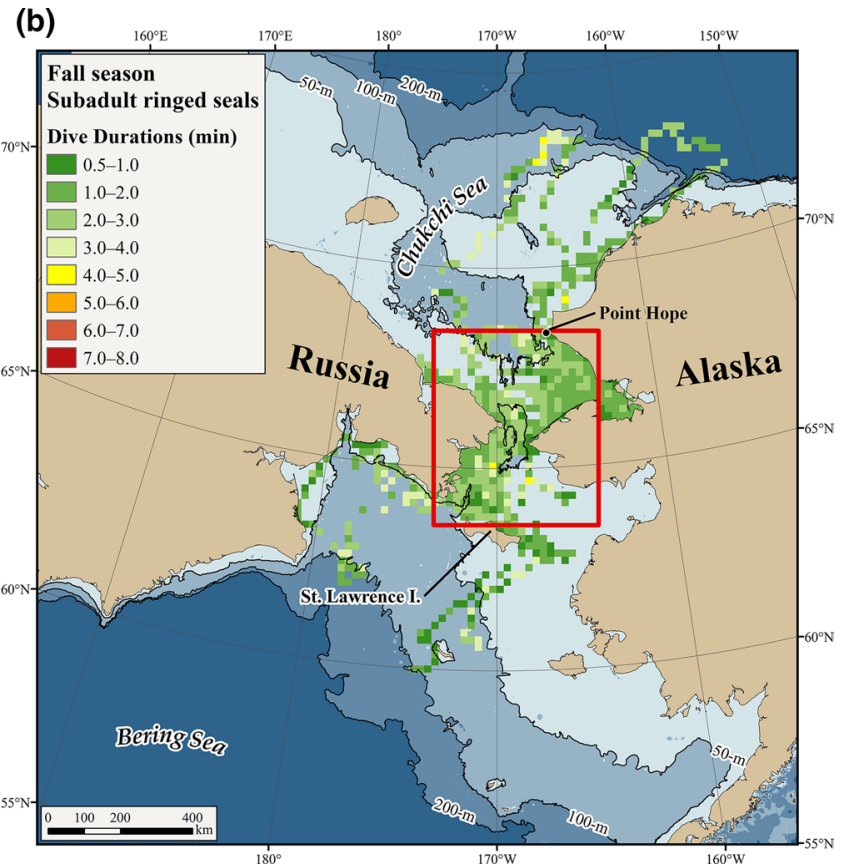

Duration indices were averaged within $20 \times 20 \mathrm{~km}$ cells. Red box represents the area of adult-subadult overlap 


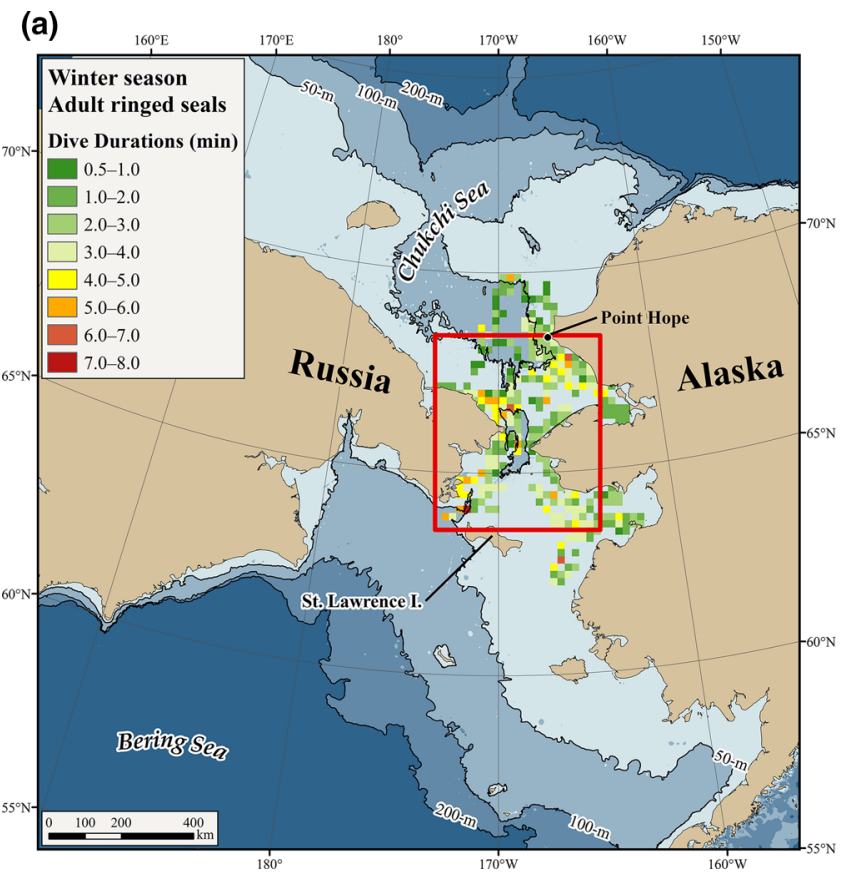

Fig. 8 Spatial distribution of dive durations of tagged a adult $(n=13)$ and b subadult $(n=12)$ ringed seals (Pusa hispida) during winter (December-March) in the Bering and Chukchi seas, 2007-2010.

annual differences in sea ice or movements. The seasonal movements of both age classes of seals tagged in 2009, however, were generally similar to seals tagged in 2007 and 2008 (Fig. 1 and Fig. 1 in Crawford et al. 2012).

We found that (1) when both age classes were in the same area, during the same seasons, dive depths were similar, otherwise, subadult seals tended to dive deeper than adults; (2) both age classes tended to haul out less and dive deeper, longer, and more often at midday than at other times of day; (3) when both age classes were in the same area, during the same seasons, adults dove longer than subadults, otherwise, both age classes tended to dive for similar durations; (4) subadults tended to make a few more dives per hour than adults; and (5) dive and haul-out behaviors did not differ by sex.

We found that when subadult and adult seals were located in the same areas, during the same season (i.e., the waters between St. Lawrence Island and Point Hope) they dove to similar depths, which is not surprising given these waters are relatively shallow $(\bar{x}=30 \mathrm{~m}$ depth) and there would be no physiological reason that adults and subadults could not dive to similar depths, possibly targeting similar prey. Although most phocids typically acquire much of their diving ability within the first few months of life (e.g., Lydersen and Hammill 1993; Noren et al. 2005; Bennett et al. 2010; Blanchet et al. 2016), their diving abilities improve with size (Lydersen et al. 1992). Indeed, most other studies of ringed seals found that adults dive deeper than subadults (e.g., Born et al. 2004; Harwood et al. 2015). In the Bering and Chukchi

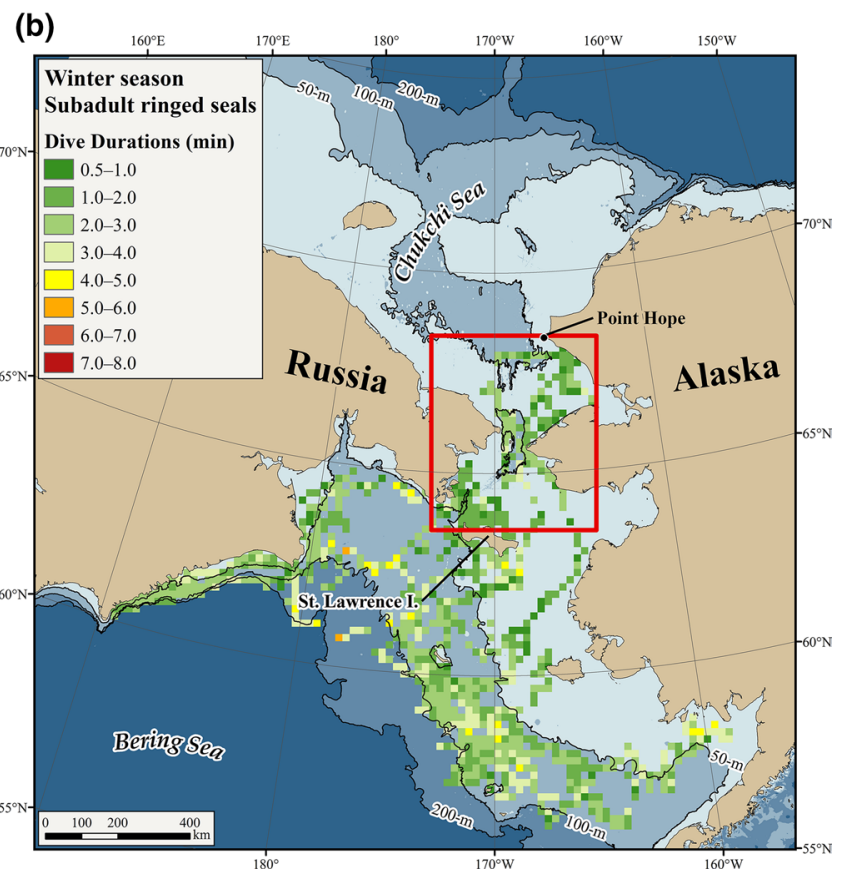

Duration indices were averaged within $20 \times 20 \mathrm{~km}$ cells. Red box represents the area of adult-subadult overlap

seas, however, subadults were generally located in deeper water in both the fall $(\bar{x}=61.3 \mathrm{~m}$ for subadults and $15.7 \mathrm{~m}$ for adults) and winter seasons ( $\bar{x}=65.9 \mathrm{~m}$ for subadults and $25.4 \mathrm{~m}$ for adults). This is because adult seals tended to be associated with breeding habitat in heavy pack or shorefast ice that occurred in shallower, coastal water of the Chukchi and northern Bering seas, while subadults followed the seasonally advancing loose pack ice southward into the relatively deeper waters of the Bering Sea (Crawford et al. 2012). That subadults dove deeper than adults when at the ice edge, but not when subadults and adults were in the same geographic region, appears to be a consequence of location. Adults in the North Water area of northern Baffin Bay, however, dove deeper (>100 m), likely to feed on cephalopods and larger size classes of Arctic cod (Boreogadus saida), than subadults $(<50 \mathrm{~m})$, which likely fed on ice-associated amphipods and smaller size classes of Arctic cod found at shallow depths (Born et al. 2004). Subadults in the eastern Beaufort Sea made more shallow dives $(<100 \mathrm{~m})$ during the open-water season than adults (Harwood et al. 2015). Adults also dove deeper than subadults in Barrow Strait, Canada (Kelly and Wartzok 1996).

That both age classes tended to haul out less, dive deeper, longer, and more often at midday than at other times of day (Figs. 2-4 and Online Resource 3) suggests that seals could be following the vertical migrations of their prey. Many invertebrates, including euphausiids, copepods, and pelagic amphipods, migrate to deeper depths during the day to avoid 
visual predators (Gulliksen 1984; Teilmann et al. 1999; De Robertis and Cokelet 2012). Thus, foraging fish, including Arctic and saffron cod (Eleginus gracilis) (Crawford and Jorgenson 1990), and seals may also dive to deeper depths when feeding during the day and shallower depths at night. However, despite our finding that both adult and subadult ringed seals dove deeper at midday, we know of no published reports of diel vertical migrations of plankton at water depths $<50 \mathrm{~m}$. Perhaps, prey are more concentrated when they are deeper at midday. The additional depth associated with foraging at midday compared to other times of day was typically $<20 \mathrm{~m}$, and likely requires minimal additional energetic cost. Ringed seals in Franklin Bay, Canada, generally made deeper dives more frequently in daytime than at night during winter (December-April) (Benoit et al. 2010). Subadult ringed seals also dove deeper during midday and shallower at night in other regions, matching the diel vertical migrations of amphipods (Themisto libellula) and Arctic cod in the North Water polynya of northern Baffin Bay, when in similarly shallow waters $<100 \mathrm{~m}$ (Teilmann et al. 1999). Although ringed seals rely primarily on vision to find breathing holes (Elsner et al. 1989) and likely to find prey, they probably are not wholly dependent on vision to forage. Certainly, adult ringed seals under thick ice during winter cannot depend on light, even during midday, for foraging. Sound and water movement may also be important. Ringed seals responded quickly and accurately to sound during navigation experiments (Elsner et al. 1989). Seal whiskers are highly innervated (Dykes 1975; Marshall et al. 2006) and likely capable of detecting pressure waves that may be used to detect and capture prey in dark and turbid water (Hyvärinen and Katajisto 1984; Hyvärinen 1989, 1995; Dehnhardt et al. 2001).

Different diving patterns at midday were not observed in two of three studies conducted during the same seasons as ours in waters between Greenland and Canada. No diel pattern in ringed seal dive and haul-out behavior was apparent to Born et al. (2002) or Heide-Jørgensen et al. (1992); however, subadult ringed seals in the North Water Polynya dove more often at midday in October and November (Teilmann et al. 1999).

In general, ringed seal dives were of short duration, with average durations ranging from approximately 1.5 to $3 \mathrm{~min}$ (Fig. 3). Other studies also found many ringed seal dives were less than $5 \mathrm{~min}$ and most were less than 10 min (Kelly and Wartzok 1996; Gjertz et al. 2000; Harwood et al. 2015). Such durations are shorter than those of many other phocids (e.g., northern elephant seals, Mirounga angustirostris; Weddell seals, Leptonychotes weddellii; harbor seals, Phoca vitulina; and harp seals, Pagophilus groenlandicus; Delong and Stewart 1991; Testa 1994; Suryan and Harvey 1998; Folkow and Blix 1999). However, increased physiological capabilities are associated with larger body mass and ringed seals are considerably smaller than other phocids. Therefore, smaller body mass is likely partly responsible for the shorter dive durations observed in ringed seals. When both age classes were in the same area, during the same season, adults dove, on average, 0.6-1.0 min longer than subadults (Figs. 7 and 8). Other studies also found that adults tend to dive longer than subadults (Kelly and Wartzok 1996; Kunnasranta et al. 2002; Harwood et al. 2012, 2015), although body mass may be a better predictor of maximal dive duration than age (Lydersen et al. 1992). Longer dives by adults are likely due to a combination of greater physiological capabilities, more experience finding prey, and, when in shorefast ice, more restricted opportunities to reach the surface through breathing holes. When adults and subadults were in different areas, however, dive durations were similar (Fig. 3), likely because subadults dove deeper while in deeper waters than adults.

Dives were generally longer during midday, when seals were also diving deeper. Adult seals tended to dive for longer periods during winter than they did during fall, perhaps because they are restricted to surfacing at breathing holes and may have to range farther to find food. Although durations were longer during winter than fall, the seasonal pattern was not as distinct for subadult seals, perhaps because their winter habitat of broken pack ice allows similar surfacing opportunities as their fall habitat (i.e., not restricted to breathing holes), or perhaps feeding opportunities and prey depths are similar for subadults between seasons.

Although subadult seals did not dive as long as adults when in the same area, they tended to make more dives per hour; typically, subadults dove 1-5 more times per hour than adults. Although the hourly difference in rate is small, over the course of a day, subadults made an average of 97 more dives per day than adults during fall and 71 more dives per day than adults during winter. A cursory look at the time seals spent at the surface ( $0-2 \mathrm{~m})$ and diving $(>2 \mathrm{~m})$ using the TAD data revealed that subadults and adults spent similar amounts of time diving during the fall $(13.0 \mathrm{~h}$ and $12.6 \mathrm{~h})$ and winter (13.7 $\mathrm{h}$ and $13.3 \mathrm{~h}$ ), which matches closely with extrapolations of time spent diving from the duration and rate summaries and is further supported by similar haulout probabilities between age classes during fall and winter. Therefore, subadults and adults foraged for the same amount of time, but they used subtly different strategies. Over the course of a day, subadults made more shorter dives and adults made fewer longer dives. Perhaps subadults maximize foraging opportunities by diving more frequently to compensate for their shorter dive durations until they can increase their foraging efficiency. Our results suggest that subadults are physiologically adapted to dive as deep as adults in the shallow Bering and Chukchi basin, which is supported by studies that show seals begin developing their diving ability within the first few months of life (e.g., Lydersen and 
Hammill 1993; Noren et al. 2005; Bennett et al. 2010; Blanchet et al. 2016). Their development of aerobic dive capabilities and oxygen storage capacity, however, may take longer and prevent them from diving as long as adults (Lydersen et al. 1992). Similar times spent at and on the surface also suggest that neither age class incurs additional physiological costs due to diving that requires more time resting even though adults maintain breathing holes and subadults allocate their energy toward growth during the winter. Similar amounts of time spent at and on the surface suggests that the dive duration and rate strategies used by subadults and adults, while different, are equivalent in their energetic cost. Dive rate for ringed seals in the North Water area of northern Baffin Bay was associated with age (or mass); there, seals $<2$ years old dove more often than seals $\sim 3$ years old, which dove more often than adults (Born et al. 2004). Specifically, subadults dove 9-10 more times per hour than adults; 227 more times per day (Born et al. 2004).

Haul-out behavior of adults and subadults was remarkably similar during both seasons in this study (Fig. 4). Both age classes were less likely to haul out at midday than other times of day during our study period (September-March). In comparison, there was no diel pattern in haul-out behavior for two seals monitored between June and October off northwest Greenland (Heide-Jørgensen et al. 1992). Similar to our study, ringed seals in Svalbard, Norway, hauled out 5-20\% of the time between August and May and the amount of time hauled out was highest in spring (Hamilton et al. 2018). The haul-out pattern identified in our study is the opposite of that observed during the spring molt (May-June) (Kelly and Quakenbush 1990). To speed hair growth during molt, seals haul out in the sun (midday) to elevate skin temperature (McLaren 1958; Feltz and Fay 1966). Although we expect adult females to spend more time hauled out toward the end of winter (beginning in March) when they are constructing birth lairs for pupping and nursing pups, we did not observe this, perhaps because they did not restrict their movements to small areas in shorefast ice, as would be expected if they were maintaining a birth lair or nursing pups, or our sample size was too small. Similar to our study, there was also no difference in time hauled out between the sexes of ringed seals in Svalbard, Norway, likely due to the small sample size in the spring (Hamilton et al. 2018).

We found no differences in dive or haul-out behaviors between sexes in any comparisons. Previous studies, however, identified differences in dive behavior by sex. Female ringed seals in the North Water polynya often dove shallower and for shorter durations than males (Teilmann et al. 1999). During winter, adult female ringed seals in the eastern Beaufort Sea, Canada, however, made more deep (200-500 m) and longer (10-18 min) dives than adult males (Harwood et al. 2015).
It is likely that subadults dove deeper during winter when they were close to the southern ice edge and Bering Sea shelf break because of the deeper distribution of their prey in deeper water. The presence of canyons, Bering and Pribilof canyons in the southeast and Zhemchug Canyon in the northwest, helps to concentrate zooplankton and fish for marine mammals and birds, making this region an extremely productive area (Vestfals et al. 2014). In addition, physical features and processes at the shelf break, including winter winds, upwelling, eddies, and advection facilitate the redistribution of nutrients, on-shelf transport, and concentrate prey (Schneider 1982; Woodby 1984; Hunt 1991; Russell et al. 1999; Hunt et al. 2002; Bost et al. 2009; Gibson et al. 2013; Vestfals et al. 2014).

In the Bering and Chukchi seas, adult ringed seals eat Arctic cod and saffron cod (Lowry et al. 1980; Lowry and Frost 1981a), rainbow smelt (Osmerus mordax; Quakenbush et al. 2011; Crawford et al. 2015), and crustaceans (gammarid amphipods, mysids, and shrimps; Lowry et al. 1980; Lowry and Frost 1981a; Crawford et al. 2015). Subadults also consume crustaceans and smaller size classes of Arctic cod (Lowry et al. 1980; Lowry and Frost 1981a). Ringed seals and Arctic cod both consume amphipods, mysids, and shrimp (Lowry and Frost, 1981b); therefore, where these crustaceans are located in the water column will likely be the focus depth for foraging seals. Gjertz et al. (2000) suggested that shallow diving $(<50 \mathrm{~m})$ ringed seals in pack ice near Svalbard fed mainly on ice-associated species, including zooplankton. Zooplankton available to subadults in the middle-shelf of the ice-covered Bering Sea include euphausiids that migrate up from deeper depths during midday to near-surface waters at night (Woodby 1984; De Robertis and Cokelet 2012; Ressler et al. 2012). Oceanic copepods (Neocalanus spp.), not known to be eaten directly by ringed seals, migrate to the upper water column in January and February (Gibson et al. 2013) and are prey for fish including walleye pollock (Gadus chalcogrammus) that move onto the middleshelf where warmer water is upwelled, and capelin (Mallotus villosus) that winter offshore (Woodby 1984; De Robertis and Cokelet 2012). Most studies of ringed seal foraging behavior in the Bering and Chukchi seas (e.g., Lowry et al. 1980; Crawford et al. 2015) have relied on the examination of stomach contents from seals harvested near Alaska Native communities, which primarily represent prey consumed during the prior 6-24 h (Murie and Lavigne 1986). There are few coastal communities near the southern ice edge in the Bering Sea and fewer opportunities to examine stomach contents from seals in the central Bering Sea where most subadults over-winter. As such, little is known about the diet of subadult ringed seals in the central Bering Sea, when they are near the southern ice edge. Other methods that enable inference into their dietary history, weeks or months before seals are harvested in coastal communities, such as fatty acid 
or stable isotope analyses (Post 2002; Iverson et al. 2004; Dehn et al. 2007; Carroll et al. 2013; Young and Ferguson 2013; Wang et al. 2016), may reconstruct the winter diet of subadult seals after they are harvested in the spring during their northward migration. Such techniques provide a coarse view of diet, often only identifying prey to higher taxonomic levels, such as family; however, they may provide information on dominant winter fish prey that would explain the winter dive behavior we observed for subadult ringed seals.

This is the first study of ringed seal dive behavior that investigated more than one season and age class in the Chukchi and Bering seas. Adults and subadults were remarkably similar in their dive behavior when in similar areas and remarkably similar in their haul-out behavior in general. While differences in movements between age classes are likely influenced by a combination of factors, including sea ice (Hamilton et al. 2016, 2018), the use of breeding territories and breathing holes in shorefast ice, risk of predation, and differences in the distribution and abundance of prey (Crawford et al. 2012), the similarities in dive and haul-out behavior are likely due to their similar diet and that subadults develop diving abilities within months of their birth (Noren et al. 2005; Bennett et al. 2010; Blanchet et al. 2016).

Acknowledgements This study was conducted through extensive cooperation by the Native Village of Kotzebue and the Alaska Department of Fish and Game (ADF\&G). The success of the study was largely due to assistance from "hunter-biologists" John Goodwin, Edward Ahyakak, Jeff Barger, Brenda Goodwin, Cyrus Harris, Doc Harris III, Grover Harris, Grover Harris Jr., Lee Harris, Levi Harris, Jerry Jones, James Monroe, and Pearl Goodwin. We could not have conducted this study without John Goodwin's extensive knowledge of local environmental conditions and seal behavior and his commitment to making this project a success. We thank John Citta for his statistical insights and constructive comments. The Selawik National Wildlife Refuge provided housing for the field crew in Kotzebue. This project was funded by a U.S. Department of the Interior, Tribal Wildlife Grant for Federally Recognized Tribes; Shell Exploration and Production Co.; National Fish and Wildlife Foundation with funding from Conoco Phillips; the Native Village of Kotzebue, the National Marine Fisheries Service Alaska Region, and the National Oceanic and Atmospheric Administration through ADF\&G Grant Nos. NA05NMF4391187 and NA08NMF4390544. Ringed seal tagging was conducted under NMFS Research Permit No. 358-1787-01 issued to ADF\&G and an approved protocol by the ADF\&G Animal Care and Use Committee (No. 06-16).

\section{Compliance with ethical standards}

Conflict of interest The authors declare that they have no conflict of interest.

Ethical approval Animal handling procedures were approved by the Alaska Department of Fish and Game (ADFG) Animal Care and Use Committee No. 06-16. All applicable international, national, and institutional guidelines for the care and use of animals were followed in accordance with the ethical standards of ADFG. The capture and tagging of ringed seals was conducted under National Marine Fisheries Service, Scientific Research Permit No. 358-1787-01 issued to ADFG.
Open Access This article is distributed under the terms of the Creative Commons Attribution 4.0 International License (http://creativeco mmons.org/licenses/by/4.0/), which permits unrestricted use, distribution, and reproduction in any medium, provided you give appropriate credit to the original author(s) and the source, provide a link to the Creative Commons license, and indicate if changes were made.

\section{References}

Bennett KA, McConnell BJ, Moss SEW, Speakman JR, Pomeroy PP, Fedak MA (2010) Effects of age and body mass on development of diving capabilities of gray seal pups: costs and benefits of the postweaning fast. Physiol Biochem Zool 83:911-923

Benoit D, Simard Y, Gagné J, Geoffroy M, Fortier L (2010) From polar night to midnight sun: photoperiod, seal predation, and the diel vertical migrations of polar cod (Boreogadus saida) under landfast ice in the Arctic Ocean. Polar Biol 33:1505-1520. https ://doi.org/10.1007/s00300-00010-00840-x

Blanchet M-A, Lydersen C, Ims RA, Kovacs KM (2016) Making it through the first year: ontogeny of movement and diving behavior in harbor seals from Svalbard, Norway. Mar Mamm Sci 32:1340 1369. https://doi.org/10.1111/mms.12341

Born EW, Teilmann J, Riget FF (2002) Haul-out activity of ringed seals (Phoca hispida) determined from satellite telemetry. Mar Mamm Sci 18:167-181

Born EW, Teilmann J, Acquarone M, Riget FF (2004) Habitat use of ringed seals (Phoca hispida) in the North Water area (North Baffin Bay). Arctic 57:129-142

Bost CA, Cotté C, Bailleul F, Cherel Y, Charrassin JB, Guinet C, Ainley DG, Weimerskirch H (2009) The importance of oceanographic fronts to marine birds and mammals of the southern oceans. J Mar Syst 78:363-376. https://doi.org/10.1016/j.jmars ys.2008.11.022

Bradstreet MS, Cross WE (1982) Trophic relationships at high arctic ice edges. Arctic 35:1-12

Burns JJ (1970) Remarks on the distribution and natural history of pagophilic pinnipeds in the Bering and Chukchi seas. J Mammal 51:445-454

Burns JJ, Kelly BP, Frost KJ (1981) Trophic relationships among ice-inhabiting phocid seals and functionally related marine mammals. US Dep Commer, NOAA, Outer Continental Shelf Environmental Assessment Program, Annual Report RU \#232. Washington, DC, USA

Carroll SS, Horstmann-Dehn L, Norcross BL (2013) Diet history of ice seals using stable isotope ratios in claw growth bands. Can J Zool 91:191-202. https://doi.org/10.1139/cjz-2012-0137

Cavalieri D, Markus T, Comiso JC (2004, updated daily) AMSR-E/ Aqua Daily L3 $12.5 \mathrm{~km}$ Brightness Temperature, Sea Ice Concentration, and Snow Depth Polar Grids V002. National Snow and Ice Data Center. Boulder, Colorado, USA, https://nsidc.org/

Chapskii KK (1940) The ringed seal of western seas of the Soviet Arctic (The morphological characteristic, biology and hunting production). Tr Vses Arkt Inst Leningrad 145:1-72 (Translated from Russian by Fish Res Bd Can, 1971, Translation Series 1665)

Crawford RE, Jorgenson JK (1990) Density distribution of fish in the presence of whales at the Admiralty Inlet landfast ice edge. Arctic 43:215-222

Crawford JA, Frost KJ, Quakenbush LT, Whiting A (2012) Different habitat use strategies by subadult and adult ringed seals (Phoca hispida) in the Bering and Chukchi seas. Polar Biol 35:241-255. https://doi.org/10.1007/s00300-011-1067-1 
Crawford JA, Quakenbush LT, Citta JJ (2015) A comparison of ringed and bearded seal diet, condition and productivity between historical (1975-1984) and recent (2003-2012) periods in the Alaskan Bering and Chukchi seas. Prog Oceanogr 136:133-150. https:// doi.org/10.1016/j.pocean.2015.05.011

Danielson S, Johnson M, Solomon S, Perrie W (2008) Alaska Ocean Observing System Digital Elevation Model, v.1.03 https://www. aoog.org/

De Robertis A, Cokelet ED (2012) Distribution of fish and macrozooplankton in ice-covered and open-water areas of the eastern Bering Sea. Deep Sea Res II 65-70:217-229

Dehn L-A, Sheffield GG, Follmann EH, Duffy LK, Thomas DL, O'Hara TM (2007) Feeding ecology of phocid seals and some walrus in the Alaskan and Canadian Arctic as determined by stomach contents and stable isotope analysis. Polar Biol 30:167-181

Dehnhardt G, Mauck B, Hanke W, Bleckmann H (2001) Hydrodynamic trail-following in harbor seals (Phoca vitulina). Science 293:102-104

Delong RA, Stewart BS (1991) Diving patterns of northern elephant seal bulls. Mar Mamm Sci 7:369-384

Dykes RW (1975) Afferent fibers of mystacial vibrissae of cats and seals. J Neurophysiol 38:650-662

Elsner R, Wartzok D, Sonofrank NB, Kelly BP (1989) Behavioral and physiological reaction of arctic seals during under-ice pilotage. Can J Zool 67:2506-2513

ESRI Inc. (2010) ArcGIS Desktop: Release 10.0. Environmental Systems Research Institute, Redlands, CA, USA

Fancy SG, Pank LF, Douglas DC, Curby CH, Garner GW, Amstrup SC, Regelin WL (1988) Satellite telemetry: a new tool for wildlife research and management. US Fish and Wildl Serv, Washington, DC, USA, Res Pub 172

Fedak MA, Anderson SS, Curry MG (1983) Attachment of a radio tag to the fur of seals. J Zool 200:298-300

Feltz ET, Fay FH (1966) Thermal requirements in vitro of epidermal cells from seals. Cryobiology 3:261-264

Folkow LP, Blix AS (1999) Diving behaviour of hooded seals (Cystophora cristata) in the Greenland and Norwegian seas. Polar Biol 22:61-74

Folkow LP, Nordøy ES, Blix AS (2004) Distribution and diving behaviour of harp seals (Pagophilus groenlandicus) from the Greenland Sea stock. Polar Biol 27:281-298

Folkow LP, Nordøy ES, Blix AS (2010) Remarkable development of diving performance and migrations of hooded seals (Cystophora cristata) during their first year of life. Polar Biol 33:433-441

Freitas C, Kovacs KM, Ims RA, Fedak MA, Lydersen C (2008a) Ringed seal post-moulting movement tactics and habitat selection. Oecologia 155:193-204

Freitas C, Lydersen C, Fedak MA, Kovacs KM (2008b) A simple new algorithm to filter marine mammal Argos locations. Mar Mamm Sci 24:315-328

Frost KJ, Lowry LF (1981) Ringed, Baikal and Caspian seals-Phoca hispida, Phoca sibirica, and Phoca caspica. In: Ridgway SH and Harrison RJ (eds) Handbook of Marine Mammals. Vol 2: Seals. Academic Press, New York, NY, USA, pp 29-53

Frost KJ, Simpkins MA, Lowry LF (2001) Diving behavior of subadult and adult harbor seals in Prince William Sound, Alaska. Mar Mamm Sci 17:813-834

Furgal CM, Innes S, Kovacs KM (1996) Characteristics of ringed seal, Phoca hispida, subnivean structures and breeding habitat and their effects on predation. Can J Zool 74:858-874

Gibson GA, Coyle KO, Hedstrom K, Curchitser EN (2013) A modeling study to explore on-shelf transport of oceanic zooplankton in the Eastern Bering Sea. J Mar Syst 121-122:47-64. https://doi. org/10.1016/j.jmarsys.2013.03.010
Gjertz I, Kovacs KM, Lydersen C, Wiig Ø (2000) Movements and diving of adult ringed seals (Phoca hispida) in Svalbard. Polar Biol 23:651-656

Grebmeier JM, Cooper LW, Feder HM, Sirenko BI (2006) Ecosystem dynamics of the Pacific-influenced Northern Bering and Chukchi seas in the Amerasian Arctic. Prog Oceanogr 71:331-361

Gulliksen B (1984) Under-ice fauna from Svalbard waters. Sarsia 69:17-23

Hamilton CD, Kovacs KM, Ims RA, Lydersen C (2018) Haul-out behaviour of Arctic ringed seals (Pusa hispida): inter-annual patterns and impacts of current environmental change. Polar Biol. https://doi.org/10.1007/s00300-018-2260-2

Hamilton CD, Lydersen C, Ims RA, Kovacs KM (2016) Coastal habitat use by ringed seals Pusa hispida following a regional sea-ice collapse: importance of glacial refugia in a changing Arctic. Mar Ecol Prog Ser 545:261-277. https://doi.org/10.3354/meps11598

Hammill MO, Smith TG (1989) Factors affecting the distribution and abundance of ringed seal structures in Barrow Strait, Northwest Territories. Can J Zool 67:2212-2219

Harris RB, Fancy SG, Douglas DC, Garner GW, Amstrup SC, McCabe TR, Pank LF (1990) Tracking wildlife by satellite: current systems and performance. US Fish and Wildl Serv, Washington, DC, USA, Tech Rep 30

Harwood LA, Smith TG, Auld JC (2012) Fall migration of ringed seals (Phoca hispida) through the Beaufort and Chukchi seas, 2001-02. Arctic 65:35-44

Harwood LA, Smith TG, Auld JC, Melling H, Yurkowski DJ (2015) Seasonal movements and diving of ringed seals, Pusa hispida, in the western Canadian Arctic, 1999-2001 and 2010-2011. Arctic 68:193-209. https://doi.org/10.14430/arctic4479

Hastings KK, Frost KJ, Simpkins MA, Pendleton GW, Swain UG, Small RJ (2004) Regional differences in diving behavior of harbor seals in the Gulf of Alaska. Can J Zool 82:1755-1773

Heide-Jørgensen MP, Stewart BS, Leatherwood S (1992) Satellite tracking of ringed seals Phoca hispida off northwest Greenland. Ecography 15:56-61

Hunt GL Jr (1991) Occurrence of polar seabirds at sea in relation to prey concentrations and oceanographic factors. Polar Res 10:553-559

Hunt GL Jr, Stabeno PJ, Walters GE, Sinclair EH, Brodeur RD, Napp JM, Bond NA (2002) Climate change and control of the southeastern Bering Sea pelagic ecosystem. Deep Sea Res II 49:5821-5853

Hyvärinen H (1989) Diving in darkness: whiskers as sense organs of the ringed seal (Phoca hispida saimensis). J Zool 218:663-678

Hyvärinen H (1995) Structure and function of the vibrissae of the ringed seal (Phoca hispida L.). In: Kastelein RA, Thomas JA, Nachtigall PA (eds) Sensory systems of aquatic mammals. The Netherlands, De Spil, Woerden, pp 429-445

Hyvärinen H, Katajisto H (1984) Functional structure of the vibrissae of the ringed seal (Phoca hispida Schr.). Acta Zool Fenn 171:17-30

Iverson SJ, Field C, Bowen WD, Blanchard W (2004) Quantitative fatty acid signature analysis: a new method of estimating predator diets. Ecol Monogr 74:211-235

Johnson DS, London JM, Lea M-A, Durban JW (2008) Continuoustime correlated random walk model for animal telemetry data. Ecology 89:1208-1215

Kelly BP, Quakenbush LT (1990) Spatiotemporal use of lairs by ringed seals (Phoca hispida). Can J Zool 68:2503-2512

Kelly BP, Wartzok D (1996) Ringed seal diving behavior in the breeding season. Can J Zool 74:1547-1555

Kelly BP, Badajos OH, Kunnasranta M, Moran JR, Martinez-Bakker M, Wartzok D, Boveng PL (2010a) Seasonal home ranges and fidelity to breeding sites among ringed seals. Polar Biol 33:1095-1109 
Kelly BP, Bengtson JL, Boveng PL, Cameron MF, Dahle SP, Jansen JK, Logerwell EA, Overland JE, Sabine CL, Waring GT, Wilder JM (2010b) Status review of the ringed seal (Phoca hispida). US Dep Commer, NOAA Tech Memo. NMFS-AFSC-212

Krafft BA, Kovacs KM, Lydersen C (2007) Distribution of sex and age groups of ringed seals Pusa hispida in the fast-ice breeding habitat of Kongsfjorden, Svalbard. Mar Ecol Prog Ser 335:199-206

Kunnasranta M, Hyvärinen H, Häkkinen J, Koskela JT (2002) Dive types and circadian behaviour patterns of Saimaa ringed seals Phoca hispida saimensis during the open-water season. Acta Theriol 47:63-72

Lowry LF, Frost KJ (1981a) Distribution, growth, and foods of Arctic cod (Boreogadus saida) in the Bering, Chukchi, and Beaufort seas. Can Field Nat 95:186-191

Lowry LF, Frost KJ (1981b) Feeding and trophic relationships of phocid seals and walruses in the eastern Bering Sea. In: Hood DW and Calder JA (eds) The eastern Bering Sea shelf: oceanography and resources, Vol 2 US Dep Commer Off Mar Pollut Assessment, NOAA, Rockville, MD, USA, pp 813-824

Lowry LF, Frost KJ, Burns JJ (1980) Variability in the diet of ringed seals, Phoca hispida, in Alaska. Can J Fish Aquat Sci 37:2254-2261

Lowry LF, Frost KJ, Davis R, DeMaster DP, Suydam RS (1998) Movements and behavior of satellite-tagged spotted seals (Phoca lar$g h a)$ in the Bering and Chukchi Seas. Polar Biol 19:221-230

Lydersen C, Hammill MO (1993) Diving in ringed seal (Phoca hispida) pups during the nursing period. Can J Zool 71:991-996

Lydersen C, Ryg MS, Hammill MO, O’Brien PJ (1992) Oxygen stores and aerobic dive limit of ringed seals (Phoca hispida). Can J Zool 70:458-461

Marshall CD, Amin H, Kovacs KM, Lydersen C (2006) Microstructure and innervation of the mystacial vibrissal follicle-sinus complex in bearded seals, Erignathus barbatus (Pinnipedia: Phocidae). Anat Rec A 288A:13-25. https://doi.org/10.1002/ar.a.20273

McLaren IA (1958) The biology of the ringed seal (Phoca hispida Schreber) in the eastern Canadian Arctic. Bull Fish Res Bd Can 118:1-97

Murie DJ, Lavigne DM (1986) Interpretation of otoliths in stomach content analyses of phocid seals: quantifying fish consumption. Can J Zool 64:1152-1157

Nordøy ES, Folkow LP, Potelov VA, Prischemikhin V, Blix AS (2008) Seasonal distribution and dive behaviour of harp seals (Pagophilus groenlandicus) of the White Sea-Barents Sea stock. Polar Biol 31:1119-1135

Noren SR, Iverson SJ, Boness DJ (2005) Development of the blood and muscle oxygen stores in gray seals (Halichoerus grypus): implications for juvenile diving capacity and the necessity of a terrestrial postweaning fast. Physiol Biochem Zool 78:482-490

Post DM (2002) Using stable isotopes to estimate trophic position: models, methods, and assumptions. Ecology 83:703-718

Quakenbush LT, Citta JJ, Crawford JA (2011) Biology of the ringed seal (Phoca hispida) in Alaska, 1960-2010. Alaska Department of Fish and Game, Unpublished report to NMFS

R Core Team (2014) R: a language and environment for statistical computing. R Foundation for Statistical Computing, Vienna, Austria

Ramsey FL, Schafer DW (2002) The statistical sleuth: a course in methods of data analysis. Duxbury, Pacific Grove, CA, USA

Reeves RR (1998) Distribution, abundance and biology of ringed seals (Phoca hispida): an overview. In: Heide-Jørgensen MP, Lydersen C (eds) Ringed seals in the North Atlantic. The North Atlantic Marine Mammal Commission, Tromsø, Norway, pp 9-43

Ressler PH, De Robertis A, Warren JD, Smith JN, Kotwicki S (2012) Developing an acoustic survey of euphausiids to understand trophic interactions in the Bering Sea ecosystem. Deep Sea Res II 65-70:184-195. https://doi.org/10.1016/j.dsr2.2012.02.015

Russell RW, Harrison NM, Hunt GL Jr (1999) Foraging at a front: hydrography, zooplankton, and avian planktivory in the northern Bering Sea. Mar Ecol Prog Ser 182:77-93
SAS Institute Inc. (2011) SAS 9.3 Online Documentation. Cary, North Carolina, USA

Schneider DC (1982) Fronts and seabird aggregations in the southeastern Bering Sea. Mar Ecol Prog Ser 10:101-103

Simpkins MA, Kelly BP, Wartzok D (2001) Three-dimensional analysis of search behaviour by ringed seals. Anim Behav 62:67-72. https://doi.org/10.1006/anbe.2000.1734

Smith TG (1973) Population dynamics of the ringed seal in the Canadian eastern Arctic. Bull Fish Res Bd Can 181:1-55

Smith TG (1980) Polar bear predation of ringed and bearded seals in the land-fast sea ice habitat. Can J Zool 58:2201-2209

Smith TG, Hammill MO (1981) Ecology of the ringed seal, Phoca hispida, in its fast-ice breeding habitat. Can J Zool 59:966-981

Smith TG, Stirling I (1975) The breeding habitat of the ringed seal (Phoca hispida); the birth lair and associated structures. Can J Zool 53:1297-1305

Springer AM, McRoy CP, Flint MV (1996) The Bering Sea green belt: shelf-edge processes and ecosystem production. Fish Oceanogr 5:205-223

Stewart BS, Leatherwood S, Yochem PK, Heide-Jørgensen MP (1989) Harbor seal tracking and telemetry by satellite. Mar Mamm Sci 5:361-375

Stewart BS, Petrov EA, Baranov EA, Timonin A, Ivanov M (1996) Seasonal movements and dive patterns of juvenile Baikal seals, Phoca sibirica. Mar Mamm Sci 12:528-542

Stirling I (1974) Midsummer observations on the behavior of wild polar bears (Ursus maritimus). Can J Zool 52:1191-1198

Stirling I (1997) The importance of polynyas, ice edges, and leads to marine mammals and birds. J Mar Syst 10:9-21

Stirling I (2002) Polar bears and seals in the Eastern Beaufort Sea and Amundsen Gulf: a synthesis of population trends and ecological relationships of three decades. Arctic 55:59-76

Suryan RM, Harvey JT (1998) Tracking harbor seals (Phoca vitulina richardsi) to determine dive behavior, foraging activity, and haulout site use. Mar Mamm Sci 14:361-372

Teilmann J, Born EW, Acquarone M (1999) Behaviour of ringed seals tagged with satellite transmitters in the North Water polynya during fast-ice formation. Can J Zool 77:1934-1946

Testa JW (1994) Over-winter movements and diving behavior of female Weddell seals (Leptonychotes weddellii) in the southwestern Ross Sea, Antarctica. Can J Zool 72:1700-1710

Vestfals CD, Ciannelli L, Duffy-Anderson JT, Ladd C (2014) Effects of seasonal and interannual variability in along-shelf and cross-shelf transport on groundfish recruitment in the eastern Bering Sea. Deep Sea Res II 109:190-203. https://doi.org/10.1016/j.dsr2.2013.09.026

Vincent C, McConnell BJ, Ridoux V, Fedak MA (2002) Assessment of Argos location accuracy from satellite tags deployed on captive gray seals. Mar Mamm Sci 18:156-166

Walsh JJ, McRoy CP (1986) Ecosystem analysis in the southeastern Bering Sea. Cont Shelf Res 5:259-288

Wang SW, Frost KJ, Whiting AV (2016) Foraging ecology of ice seals in Kotzebue Sound, Alaska: insights from fatty acid markers. Mar Mamm Sci 32:765-776. https://doi.org/10.1111/mms. 12284

Welch HE, Bergmann MA, Siferd TD, Martin KA, Curtis MF, Crawford RE, Conover RJ, Hop H (1992) Energy flow through the marine ecosystem of the Lancaster Sound region, Arctic Canada. Arctic 45:343-357

Wildlife Computers (2012) Data Analysis Program, 3.0. Redmond, WA, USA

Williams TM, Kooyman GL (1985) Swimming performance and hydrodynamic characteristics of harbor seals Phoca vitulina. Physiol Zool 58:576-589

Woodby DA (1984) The April distribution of murres and prey patches in the southeastern Bering Sea. Limnol Oceanogr 29:181-188

Young BG, Ferguson SH (2013) Seasons of the ringed seal: pelagic open-water hyperphagy, benthic feeding over winter and spring fasting during molt. Wildl Res 40:52-60. https://doi.org/10.1071/ wr12168 